\title{
The Fairness 'Dilemma' in Sharing the Nile Waters: What Lessons from the Grand Ethiopian Renaissance Dam for International Law?
}

Zeray Yihdego

School of Law, University of Aberdeen, UK

\begin{abstract}
:
The monograph enquires into the fairness dilemma in connection with the construction of the Grand Ethiopian Renaissance Dam (GERD) in light of relevant colonial-era Nile treaties, post-1990 Nile framework instruments, and international watercourses law. The GERD is now a fait accompli, but fairness considerations will continue to be vital issues in its completion, filling, and operation. The monograph argues that the GERD is a symbol of a fair share of the Nile waters by Ethiopia, the realization of which depends on, inter alia, an appropriate economic return, and prevention of significant impacts. The monograph also calls for a process to address the issue of unfair agreements, and argues that, although fairness application can be complex, the notions of procedural fairness and distributive justice can be applied to define and delineate the principle with reference to a specific treaty regime.
\end{abstract}

Keywords: Distributive Justice, GERD, Nile Basin, Procedural Fairness, Watercourses law. 


\section{Contents}

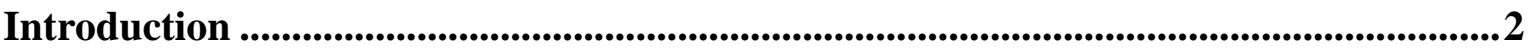

The Principle of Fairness ..............................................................................................

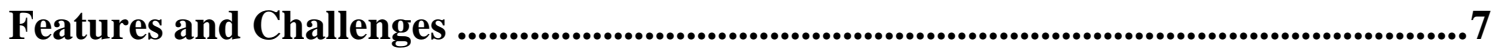

Relevance to Watercourses Law in General.....................................................................14

Relevance to an Emerging Nile Basin Legal Framework ..........................................21

Colonial-era Treaties and the Fairness of the GERD ...................................................25

The Anglo-Ethiopian Treaty 1902 and the GERD ......................................................25

The GERD's [un]Fairness in the Eyes of Colonial Treaties .......................................32

Post-1990 Nile Instruments: a way out from the fairness dilemma? ..............................37

The 1993 Framework Instrument ......................................................................................3

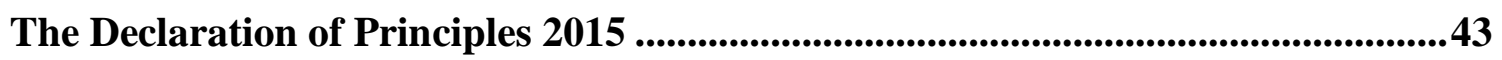

GERD's Fairness in the Eyes of post-1990 Commitments:...........................................53

GERD's Procedural Fairness ................................................................................55

GERD's Distributive Fairness............................................................................................64

Concluding Remarks: lessons to be learnt? ..................................................................77

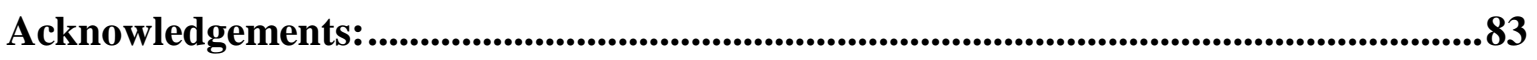

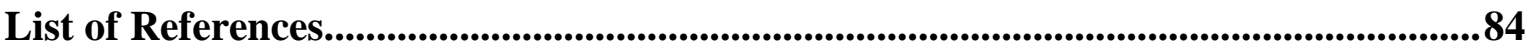

\section{Introduction}

Ethiopia's contribution to the Nile waters is attributed to the Sobat (Baro) river, which flows into, and contributes almost half of the waters of the White Nile; the Atbara (Tekeze and Angereb) river, that flows into the main stream of the Nile (and contributes $10 \%$ of Nile waters); and the Blue Nile, which is the major source of the Nile with $60 \%$ 
contribution to Nile waters. ${ }^{1}$ All these rivers make up more than $86 \%$ of Nile waters. ${ }^{2}$ The current use of the Nile waters by Ethiopia is negligible; the reasons for such a low use range from a lack of capacity and resources to a bar on the desire to utilise the water resources imposed by a colonial legacy and downstream countries. After a devastating internal civil war lasting three decades until the early 1990s, Ethiopia began to engage in sustainable development efforts, including exploring opportunities to utilise its transboundary rivers for hydro-power generation and other uses. ${ }^{3}$ As part of this effort, the Grand Ethiopian Renaissance Dam (GERD), under construction 20 kilometres from the Sudanese border since 2011 on the Blue Nile, was designed to generate 6000 megawatt (mw) in electricity. ${ }^{4}$

Inside Ethiopia, the GERD is seen as a main driver for prosperity through clean energy generation, and as a national symbol. Egypt opposed the project until recently for fear of its impact, ${ }^{5}$ but also because of the sentiment attached to the Nile as a historical gift to Egypt. ${ }^{6}$ Other Nile riparian countries, including Sudan, now support the construction of the

\footnotetext{
${ }^{1}$ Sutcliffe, J. V., \& Parks, Y. P., The Hydrology of the Nile. (IAHS Press: Wallingford, 1999) p.127 http://www.hydrosciences.fr/sierem/produits/biblio/hydrology\%20of\%20the\%20Nile.pdf. ${ }^{2}$ Ibid.

${ }^{3}$ See e.g. The Growth and Transformation Plan II (GTP II), Ethiopian National Planning Commission, May, 2016, pp.181-183.

${ }^{4}$ See Salini-Impregilo, the GERD contractor's webpage http://www.salini-impregilo.com/en/projects/in-progress/dams-hydroelectric-plants-hydraulicworks/grand-ethiopian-renaissance-dam-project.html.

${ }^{5}$ Egypt's Perspective towards the Ethiopian Grand Renaissance Dam Project (GERDP), allAfrica, http://allafrica.com/stories/201512072751.html.

${ }^{6}$ Constitution of the Arab Republic of Egypt, 18 January 2014, http://www.sis.gov.eg/Newvr/Dustor-en001.pdf, Art. 44. It reads:

"The State shall protect the River Nile, preserve Egypt's historical rights thereto, rationalize and maximize its use, and refrain from wasting or polluting its water. The State shall also protect groundwater; adopt necessary means for ensuring water security; and support scientific research in that regard.

Every citizen is guaranteed the right to enjoy the River Nile. It is prohibited to trespass the riverbank reserve or harm the riverine environment. The State shall guarantee eliminating any trespass against the River Nile as regulated by Law."
} 
GERD. ${ }^{7}$ A western advocacy group, International Rivers Network, opposed to the project for reasons of environmental concerns,${ }^{8}$ while others from Africa and elsewhere consider it as 'a symbol of Regional Integration'9 and 'an opportunity for collaboration and shared benefits in the Easter Nile Basin. ${ }^{10}$

The dam has been a source of tension between Egypt and Ethiopia ${ }^{11}$ up until President AlSisi came to power in June 2014. Subsequently, a series of painstaking negotiations among the three countries, culminated in the adoption of the 'Declaration of Principles between The Arab Republic of Egypt, the Federal Democratic Republic of Ethiopia and the Republic of the Sudan on the Grand Ethiopian Renaissance Dam Project' ('DoPs') in March 2015. ${ }^{12}$

The path to concluding the DoPs was hindered by perceived legal claims and counterclaims as well as differences over facts. Despite fundamental disagreements between Egypt and Ethiopia, a series of talks were held among the parties which led to the establishment of the International Panel of Experts (IPoE) in May 2012, at the initiation of Ethiopia, to study the effects of the dam on Egypt and the Sudan, and build confidence among the parties. The IPoE, constituted of two experts each from Egypt, Sudan and Ethiopia, and a further four international experts, published its final report on 31 May,

\footnotetext{
${ }^{7}$ Salman, S., 'The Ethiopian Renaissance Dam: Opportunities \& Challenges' Sudanow (2013) http://sudanow.info.sd/the-ethiopian-renaissance-dam-opportunities-challenges/.

8 The Grand Ethiopian Renaissance Dam Fact Sheet, International Rivers, http://www.internationalrivers.org/resources/the-grand-ethiopian-renaissance-dam-fact-sheet-8213.

${ }^{9}$ The Grand Ethiopian Renaissance Dam - A Symbol of Regional Integration, Ventures Africa, http://www.ventures-africa.com/archives/40137.

10 'The Grand Ethiopian Renaissance Dam: An Opportunity for Collaboration and Shared Benefits in the Eastern Nile Basin', MIT Abdul Latif Jameel World Water and Food Security Lab (2014) http://jwafs.mit.edu/sites/default/files/documents/GERD_2014_Full_Report.pdf.

${ }^{11}$ Kelley, M. B., \& Johnson, R. 'Egypt Is Prepared To Bomb All of Ethiopia's Nile Dams' (Stratfor Business Insider, 13 October, 2012) http://www.businessinsider.com/hacked-stratfor-emails-egyptcould-take-military-action-to-protect-its-stake-in-the-nile-2012-10\#ixzz3afm498Zg.

12 Agreement on Declaration of Principles between the Arab Republic of Egypt, the Federal Democratic Republic of Ethiopia and the Republic of the Sudan on the Grand Ethiopian $\begin{array}{lllll}\text { Renaissance Dam Project (GERDP) (DoPs), } 23 & \text { March } 2015\end{array}$ http://hornaffairs.com/en/2015/03/25/egypt-ethiopia-sudan-agreement-on-declaration-ofprinciples-full-text/.
} 
2013. The report is not publicly available in full, and, at the time, was interpreted by Egypt as a 'confirmation' of its concerns that the GERD will 'significantly harm' its interests. ${ }^{13}$ Ethiopia strongly felt it was 'vindicated' by the report as the Panel ruled-out the possibility of significant harm, rather emphasising the shared benefits and increased water flow from the GERD. ${ }^{14}$

The aftermath of the DoPs is largely dominated by a spirit of cooperation and mutual trust among Ethiopia, Sudan and Egypt. Although the DoPs is founded on modern legal principles of international watercourses law, old legal arguments are neither expressly denounced nor recognised in the Declaration. The DoPs was followed by the signing of the Khartoum minutes ${ }^{15}$ in December 2015 in which the parties reiterated their continued commitment to the DoPs, and also agreed to hire the French consultancy firms, BRLi Group and Artelia, to help them comprehend the downstream impacts of the GERD. ${ }^{16}$ This then led to the signing of a contract between the three countries and the two firms in September 2016 to conduct studies on 'Water Resources/Hydropower System Simulation Model and Transboundary Environmental and Socio-economic Impact Assessment' ${ }^{17}$ of the GERD. the precise scope, nature and purpose of the studies are not publicly known to say the least; the firms' work is planned to be finalised within 11 months beginning the end of $2016,{ }^{18}$ which may well arrive after the two GERD turbines began generating electric power, ${ }^{19}$ and the major structures of the dam are complete and ready for dam

\footnotetext{
${ }^{13}$ Supra Egypt's Perspective note 5 p. 2.

${ }^{14}$ Berhane, D., 'Anti-dam group doctor's report, joins Egypt to stop Ethiopia's dam' (Horn Affairs English, 11 April, 2014) http://hornaffairs.com/en/2014/04/11/ethiopia-dismisses-internationalrivers-as-egypts-proxy-full-text-included/.

${ }^{15}$ Salman, S., 'The Grand Ethiopian Renaissance Dam: the Road to the Declaration of Principles and the Khartoum Document' Water International (2016) Vol 41, number 4, p.512.

${ }^{16}$ Ibid, p. 523.

17 Goshu.,S., 'BRLi, Artelia Get Clearance to Conduct GERD Impact Studies' (Ethiopian Reporter, 24 September, 2016).

18 'Egypt, Ethiopia, Sudan sign final contracts on Nile dam studies' (Ahramonline, 10 September, 2016).

19 'GERD to start generate $750 \mathrm{MW}$ soon' $E B C$ (15 October, 2015)
} 
reservoir filling. ${ }^{20}$ However, the studies at issue, in particular the hydropower system simulation model, may be of vital use and help 'in the negotiations on the period of filling the GERD reservoir, ${ }^{21}$ if the parties manage to make use of them as a positive resource of cooperation rather than that of contention.

While the tripartite meetings on the GERD have been on-going in a positive spirit of promoting mutual interest of the three countries, the late 2016 civil unrest in Ethiopia led the latter to accuse Egypt, or some Egyptian institutions, of backing the violent protests in the country. President Mulatu Teshome in his address to the Ethiopian Parliament on 10 October, 2016 asserted that, 'groups and individuals which our country describe as terrorists like the Oromo Liberation Front and the Ginbot 7, work hand in hand with Egyptian institutions and are responsible for the recent destruction in our country. ${ }^{22}$ President Al-Sisi swiftly denied the Ethiopian allegation by saying that, 'Egypt does not conspire against anyone. ${ }^{23}$ He went on 'to assure the brothers in Ethiopia that Egypt has never ever offered any support to the opposition and will not carry out any conspiratorial action against Ethiopia. ${ }^{24}$ While this makes the Ethio-Egyptian relations politically fluid, ${ }^{25}$ 'the three countries have officially agreed to continue negotiations on the GERD;' the Ethio-Sudanese relationship in particular is thriving as Sudan's plan 'to build a 3000 megawatt power transmission line from the GERD ${ }^{26}$ to its cities reveals.

http://www.ebc.et/web/ennews/-/gerd-to-start-generate-750-mw-soon.

${ }^{20}$ Zhang, Y., Erkyihum, S., \& Block, P., 'Filling the GERD: evaluating hydroclimatic variability and impoundment strategies for Blue Nile riparian countries', Water International (2016) vol. 41, Issue 4, p. 594. The hydrologists in this paper predicts that filling of the GERD 'is likely to begin as early as 2018.'

${ }^{21}$ Supra Salman note 15, p. 524.

22 Boh, E., 'Ethiopia accuses Egypt of 'fuelling' violence' (Africanews, 10 October, 2016) http://www.africanews.com/2016/10/10/ethiopia-accuses-egypt-of-fueling-violence/.

${ }^{23}$ Abdelatti, A., 'Egypt's Sisi denies supporting opposition in Ethiopia' (Reuters, 13 October, 2016) http://uk.reuters.com/article/uk-ethiopia-unrest-egypt-idUKKCN12D2L5.

${ }^{24}$ Ibid.

${ }^{25}$ Zaher, A., 'Egypt-Ethiopia tension set to rise' The Arab Weekly, 2016/10/23, Issue: 78, p. 9.

26 'Sudan to build power transmission line from Ethiopia's GERD: minister' (Sudan Tribune, 28 October, 2016) http://www.sudantribune.com/spip.php?article60680. 
These topical but complex developments, coupled with the controversies surrounding old and post-1990 Nile 'commitments', make the GERD a unique example of the fairness dilemma, which entails distinct scholarly enquiry.

In light of these developments in the Nile Basin, this monograph seeks to examine three legal questions relating to the principle of fairness. The first concerns whether the GERD's [un]fairness can be judged on the basis of relevant colonial-era treaties, the 1902 (AngloEthiopian) and the 1959 Nile Treaties in particular. ${ }^{27}$ The second concerns whether the 1993 Framework Agreement between Egypt and Ethiopia, and the 2015 DoPs provide a fair justification for the construction and operation of the GERD. The last, queries whether the GERD in general, and the DoPs in particular, will have legal implications for basinlevel cooperation under or outside the Nile Basin Cooperative Framework Agreement (CFA) and international watercourses law more generally. Put differently, it queries whether or not there are lessons to be learnt from the case study for international law more generally. These and related questions cannot be tackled without explaining the nature of the principle of fairness.

\section{The Principle of Fairness}

\section{Features and Challenges}

\footnotetext{
${ }^{27}$ As discussed later (infra [colonial-era treaties and the fairness of the GERD] sec), the 1902 Nile treaty is referred to as a colonial-era treaty since Britain, one of the parties to the treaty, was in control of both Sudan and Egypt; moreover, Although the 1959 Nile Waters Agreement was concluded by the two independent states of Egypt and the Sudan, it is referred to as a colonial-era treaty in this work because most of the other Nile riparians were still under colonial domination. African states were by and large under colonial rule at the time, and the decolonisation process only began in the 1960s. See e.g. Declaration on the Granting of Independence to Colonial Countries and Peoples, 14 December 1960, Resolution 1514 (XV), United Nations General Assembly.
} 
Thomas Franck's pioneering work on fairness, ${ }^{28}$ though not the first to introduce the subject, ${ }^{29}$ argued in favour of an emerging legal principle of fairness in international law; which, he argued, could be applied to the allocation of resources, and might cover both procedural elements and distributive justice. The procedural aspect of fairness, as a legal concept, deals with participation and the involvement of concerned parties in the formulation and development of legal rules which legitimise both law-making and implementation processes ${ }^{30}$ Conversely, distributive justice, as a moral notion, deals with the essence, content and impact of laws on people, communities and states. ${ }^{31}$ This is to be determined in light of history and societal context, and is subject to the 'moderate scarcity' of resources, 'community' and 'reciprocity.' 32 Due to these characteristics two principal caveats were proposed to the fairness discourse: Firstly, absolute or non-negotiable claims over contentious rights and duties must be rejected, and secondly inequality can be tolerated or recognised as a matter of fact, so long as such an inequality ultimately serves fairness, and thus aims to narrow down an existing gap between the beneficiary and the deprived. ${ }^{33}$ When applying the fairness discourse to international law the proposition rightly assumes the existence of international law as a mature legal system, which is subject to continuous negotiations, compromises and reasoning to achieve a 'perceived fairness' by concerned parties on a specific subject matter, such as resource allocation. ${ }^{34}$

\footnotetext{
${ }^{28}$ Franck, T., Fairness in International Law and Institutions (Clarendon Press: Oxford 1995).

${ }^{29}$ Rawls, J., 'Justice as Fairness' The Philosophical Review Vol. 67(2) pp. 164-194 (1958), pp. 164-194.

${ }^{30}$ Supra Franck note 28, pp.7-8, 25.

${ }^{31}$ Ibid, pp. 8-9.

${ }^{32}$ Ibid, Franck, pp. 8-15. Franck underlined the need for an agreement on 'a core of reciprocally applicable rules' (p.12). 'Moderate scarcity' refers to 'a finite, non-renewable' and particularly in 'short global supply' (p. 9). 'Community' is meant 'a social system of continuing interaction and transaction. It is only in a community that the bedrock of shared values and developed principles necessary to any assessment of fairness is found' (pp. 9-10).

${ }^{33}$ Ibid, pp. 16-18.

${ }^{34}$ Ibid, p. 14.
} 
This whole notion of fairness is seen by some as utopian, ${ }^{35}$ while as a justified and necessary principle in the international community by others. ${ }^{36}$ The latter position seems a dominant view, as will be shown relating to international watercourses law.

However, the fairness discourse has not defined or described what the principle precisely is. Judge Owada, ${ }^{37}$ in his separate position in the Wall Advisory Opinion submitted that:

Consideration of fairness in the administration of justice requires equitable treatment of the positions of' both sides involved in the subject-matter in terms of the assessment both of facts and of law involved. ${ }^{38}$

This is in line with the common perception that fairness is synonymous with equity and justice $^{39}$ and thus shares their definition. In Roman [domestic] law, justice is seen as " the set and constant purpose which gives to every man his due. ${ }^{40}$ This appears to focus on substance than process or procedure. In contrast, For John Rawls, Justice is 'the first virtue of social institutions, as truth is of systems of thought. ...laws and institutions no matter how efficient and well-arranged must be reformed or abolished if they are unjust ${ }^{41}$. Evidently, from this definition, justice does not appear to have any meaning without fairness (and equity) and vice-versa. The emphasis placed on 'institutions' and effectiveness in defining fairness and justice poses the question whether they have been perceived restrictively to procedural and institutional questions. In contrast, Grotius

\footnotetext{
${ }^{35}$ Tasioulas, J., 'International Law and the Limits of Fairness' European Journal of International Law Vol 13(4) pp. 993-1023 (2002), pp. 993-1023; Scobbie, I., 'Tom Franck's Fairness' European Journal of International Law Vol. 13(4) pp. 909-925 (2002), pp. 909-925.

${ }^{36}$ Kritsiotis, D., 'Imagining the International Community', European Journal of International Law Vol. 13(4) pp. 961-992 (2002), p. 968; Shelton, D., 'Equity', in, Bodansky, D., Brunnee, J., \& Hey, E, The Oxford Handbook of International Environmental Law pp. 640-661 (Oxford University Press: Oxford, 2007), pp. 645-649.

${ }^{37}$ Legal Consequences of the Construction of a Wall in the Occupied Palestinian Territory Separate Opinion of Judge Owada ICJ Repts 2004.

${ }^{38}$ Ibid, p. 260.

${ }^{39}$ Supra Shelton note 36, p. 640.

${ }^{40}$ Moyle, J.B., The Institutes of Justinian, 5th ed. (Clarendon Press, Oxford, 1913) bk I, title 1 http://droitromain.upmf-grenoble.fr/Anglica/just1_Moyle.htm.

${ }^{41}$ Rawls, J., A Theory of Justice, rev. ed. (Cambridge, MA: Harvard University Press, 1999) p. 3
} 
diligently clarifies that justice is presumed to be clogged not only when it is delayed but also where a 'judgement has been rendered in a way manifestly contrary to law. ${ }^{42}$ Hence, according to Grotius, deviating from, or complying with, laws, amongst other things, constitutes the idea of justice. Again, it is not clear whether his reference to the law is meant to embrace both procedure and substance.

Steven Ratner's definition, which is beyond national law, describes

global justice as process or outcome that assigns rights and duties to global actors so that it is clear what each such actor is entitled or required to do or have. Norms of international law are just if they assign those rights and duties in a way that meets a substantive standard of justice. ${ }^{43}$

This clearly captures both procedure and content of laws in the realm of justice.

Equity, by contrast to justice, implies a general principle of law, filling gaps in the law, not applying unjust laws and adaptable interpretation and application of laws to particular cases. ${ }^{44}$ Indeed, this approach to equity appears to be broader in scope, comprising both processes and substantive matters, and possibly, going beyond the law in applying ethical and moral imperatives. For this reason, the nature of equity has been subjected to more controversy. One view broadly sees equity as 'subjective appreciation' of facts and laws in dealing with legal claims and counter-claims, ${ }^{45}$ while another view, which resembles Grotius's view on justice considers it as 'an expression of an objective idea of justice. ${ }^{46}$

42 Grotius, H., The Law of War and Peace, Book III, Chapter 2, Vol. 1 (1625). http://lonang.com/library/reference/grotius-law-war-and-peace/gro-302/.

${ }_{43}$ Ratner, R. S., The Thin Justice of International Law: A Moral Reckoning of the Law of Nations (Oxford University Press, Oxford, 2015) p 44. Italics in the original.

${ }^{44}$ Akehurst, M., 'Equity and General Principles of Law' The International and Comparative Law Quarterly Vol. 25(4) pp. 801-825 (1976), pp.801-802; McIntyre, O., 'Utilization of Shared International Freshwater Resources: The Meaning and Role of "Equity" in International Water Law' Water International Vol. 38(2) pp. 112-129. (2013), pp.114-117.

${ }^{45}$ Jennings., R., 'Equity and Equidistance Principles' Annuaire Suisse de Droit International Vol. 27, 31-35 (1986), pp. 27, 31.

${ }^{46}$ Case Concerning Pulp Mills on the River Uruguay (Argentina v Uruguay) Judgment of 20 April 2010 Separate Opinion of Judge Trindade ICJ 2010, paras. $10 \& 11$. 
From this one may deduce either justice and equity are different sides of the same coin or equity is a tool that can, or ought to, be used to articulate justice with the latter being the ultimate objective of applying laws.

Despite the broader nature of equity and its close relationship, to say the least, with justice, ${ }^{47}$ the International Court of Justice (ICJ) detached it from the notion of 'distributive justice ${ }^{48}$ without clear explanation. In contrast, Steven Ratner, building on Hart's conception of justice, writes 'in thinking about justice as relational (between different claimants' of rights/duties), it seems like we cannot escape the idea of distributions, or more precisely of allocations.... 49

Misleadingly, the debate over distributive justice is often framed in international law in the context of the North-South divide and the question of legal or moral duty to the sharing of resources between developed and developing members of the international community. ${ }^{50}$ While there is a merit in this debate which is not within the scope of this monograph, it seems to overlook distributive justice's wider appeal beyond such a divide. For example, in relation to: a) resource sharing among members of the same category (developed or developing countries), b) historical or current specific injustice by a member of one category against a member of the other category, and c) relating to special legal regimes such as international watercourses law. With this in mind, the monograph aims to probe the justifiability of the outright rejection or support for distributive justice as a legal concept.

\footnotetext{
${ }^{47}$ Lowe, V., 'The Role of Equity in International Law' Australian Yearbook of International Law Vol. 12 pp. 54-81 (1988-89), p.54; supra Akehurst note 44.

${ }^{48}$ Case Concerning the Continental Shelf (Tunisia/Libyan Arab Jamahiriya) Judgment of 24 February ICJ Repts 1982, para. 71.

${ }^{49}$ Supra Ratner note 43 . The clarification in brackets added for clarification.

50 Prost., M., \& Camprudi., A. T., 'Against Fairness? International Environmental Law, Disciplinary Bias and Pareto Justice' Leiden Journal of International Law Vol. 25(2) pp. 379-396 (2012), p.379.
} 
Given that the concepts of justice, equity and fairness are inherently interweaved with each other, this work explores their nature by applying John Rawls'51 thesis that 'the fundamental idea in the concept of justice is fairness, ${ }^{, 52}$ in all its aspects and caveats, including distributive justice, as meticulously articulated in Franck's ${ }^{53}$ fairness discourse. Given that Franck has not defined the principle of fairness, and recognising that the application of fairness, justice and equity may well vary from one field to another depending on relevant laws and the objectives therein, the principle of fairness, for the purpose of this article, will imply a system of 'fair dealing' or 'fair play' ${ }^{54}$ in relations among sovereign states, which includes transboundary resource sharing, with the aim of attaining legally acceptable, proportionate and just, as opposed to arbitrary and unequal, processes and results. ${ }^{55}$ This general description of fairness only serves as a starting point in the application of the concept to specific cases and problems.

Before applying the principle to international watercourses law, however, a few points merit consideration here. The characterisation of distributive justice by Franck as a moral or ethical, rather than legal, concept is troubling. Of course, laws and regulations are informed by [im]moral underpinnings; the fact of the matter is that substantive matters of law in fields ranging from international trade, economic law, and the law of the sea, to that of humanitarian law and human rights are predominantly a matter of law rather than abstract ethical standards. However, the fairness discourse has not denied the embodiment

\footnotetext{
${ }^{51}$ Supra Rawls note 29.

${ }^{52}$ Ibid, p.164.

${ }^{53}$ Supra Franck note 28.

${ }_{54}$ Maiese, M. \& Burgess, H., Principles of Justice and Fairness, Beyond Intractability, http://www.beyondintractability.org/print/2373.

55 Wolfrum, R., 'Commentary on Purposes and Principles (Art 1)', in, Simma, B., Khan, D. E., Nolte, G., \& Paulus, A., The Charter of the United Nations: A Commentary 3rd ed. Volume 1 pp. 113-114 (Oxford University Press: Oxford, 2012), pp.113-4; supra Tunisia/Libyan Arab Jamahiriya note 49, para. 71; Case Concerning the Gabčikovo-Nagymaros Project (Hungary v Slovakia) (ICJ 25 September 1997) 37 ILM 162 (1998), para. 147; Yihdego, Z., \& Rieu-Clarke, A., 'An exploration of fairness in international law through the Blue Nile and GERD' Water International (2016) Volume 41, Issue 4 pp. 528-549.
} 
of substantive rules of equity as fairness onto treaties and conventional arrangements, as this monograph will illustrate.

Similarly, while socio-economic or other forms of inequality (or inequity) is a fact, be it in the relations between individuals or states, its open endorsement in international law, conceptually or normatively, defeats the core values and foundations of international law, including the principles of sovereign equality and permanent sovereignty over natural resources. ${ }^{56}$ It may well be that the fairness discourse takes into account existing situations, including inequality, as one factor for determining or promoting distributive justice, ${ }^{57}$ which is not the same as recognising such disparity as a matter of principle.

The elements of 'community' of states and resource 'scarcity', as part of the principle at issue, are persuasive and imperative; the addition of 'reciprocity' as a condition to the fairness discourse can, however, be supported or challenged; some cases and claims associated with transboundary resources can be of an erga omnes, and not reciprocal, character. ${ }^{58}$ Yet reciprocity remains crucial in inter-state relations, including in the governance of trans-boundary resources, for purposes of promoting equity and mutual interest among countries. ${ }^{59}$

There is hardly a uniform definition nor a universally shared perception of the principle of fairness in its various names and terms, as a result, scholars question its existence as a

\footnotetext{
${ }^{56}$ Charter of Economic Rights and Duties of States, 12 December 1974, Resolution 3281 (XXIX), United Nations General Assembly, Arts. 2, 8, 10.

${ }^{57}$ Ibid, Art. 25; see also The Marrakesh Agreement Establishing the World Trade Organization, 1994, 1869 UNTS 299. The first preambular paragraph of the Agreement promotes inter alia 'optimal use of the world's resources... in a manner consistent with their [States] respective needs and concerns at different levels of economic development.' This appears to acknowledge and accept the economic and development levels of WTO member States. The second preambular paragraph, however, emphasises the 'need for positive efforts designed to ensure that developing countries, and especially the least developed among them, secure a share in the growth in international trade commensurate with the needs of their economic development.'

${ }^{58}$ Case Concerning the Barcelona Traction, Light and Power Company, Limited (Belgium v Spain) ICJ Second Phase Judgment of 5 February 1970. See also supra Ratner, note 43, pp. 59-62.

${ }^{59}$ The Diversion of Water from Meuse (Netherlands v Belgium) PCIJ Series A/B No 70 (28 June 1937).
} 
legal concept in international law. ${ }^{60}$ While sharing and acknowledging these qualms, the fairness discourse argues that there is an emerging recognition of equity as fairness in international case law and treaty law. ${ }^{61}$ At the very least, it is argued that, fairness constitutes a general principle of law as recognised in Article 38 (1) (c) of the I.C.J. Statute. ${ }^{62}$ The next section applies the principle of fairness to international watercourses law through the well-developed concept of equity.

\section{Relevance to Watercourses Law in General}

Equity as fairness comes with different clusters including 'corrective equity' and 'broadly conceived equity. ${ }^{63}$ The latter is a rule-based equity established by a specific treaty or policy regime. ${ }^{64}$ What it became later as the Convention on the Law of the NonNavigational Uses of International Watercourses 1997 (UNWCC) ${ }^{65}$ was used by Franck as one of the examples of applying fairness, even if it was only a draft Convention then. Franck argued that the pursuit for 'distributive justice' can be attained by considering relevant factors including socio-economic situations in riparian states for purposes of determining an 'equitable apportionment of river water' on a case-by-case-basis. ${ }^{66}$ Nearly 20 years later on from when the fairness discourse sparked a serious debate among

${ }^{60}$ Malanczuk, P., Akehurst's Modern Introduction to International Law (7th ed., Routledge: Cheltenham, 1997), pp. 54-55; Brownlie, I., Legal Status of Natural Resources in International Law (Some Aspects) (Volume 162) (Brill Nijhoff: Leiden, 1979), p. 288.

${ }^{61}$ Supra Franck note 28, 79-80.

${ }^{62}$ Supra Franck note 28, pp. 47-79.

${ }^{63}$ Ibid, pp. 56-75; supra Lowe note 48, pp.54-8; McIntyre, O., Environmental Protection of International Watercourses under International Law (Ashgate: Aldershot, 2007), p. 120.

${ }^{64}$ Supra Franck note 28, pp. 65-66.

${ }^{65}$ Convention on the Law of the Non-navigational Uses of International Watercourses, 21 May 1997, United Nations. Entered into legal force on 17 August, 2014. For some background see The International Law Commission Draft Articles on the Law of the Non-navigational Uses of International Watercourses 1994 http://legal.un.org/ilc/texts/instruments/english/commentaries/8_3_1994.pdf

${ }^{66}$ Supra Franck note 28, pp. 74-75. 
scholars, the UNWCC entered into force in August 2014; the basic rights and duties enshrined in the Convention also reflect customary international law. ${ }^{67}$ In this sense, Franck's contribution to the fairness debate in international law more generally, appears to have borne fruit, although not without challenges.

One of the challenges (or maybe opportunities) might be that the distinction between procedural and substantive law is not always a clear-cut case. The UNWCC reflects both the opportunities and challenges of the fairness discourse, consisting of detailed and complex substantive and procedural rules on the sharing and protection of transboundary water resources. The principle of equitable and reasonable utilisation, ${ }^{68}$ which tends to be a favourite of upstream countries, ${ }^{69}$ and the duty not to inflict significant harm ${ }^{70}$ as a subordinate to the equitable principle and generally favoured by downstream countries, ${ }^{71}$ constitute the core elements of distributive justice. However, international watercourses law is not merely about sharing and utilising water resources. The protection and preservation of watercourses and their natural environment ${ }^{72}$ as a legal principle constitutes part of distributive justice. ${ }^{73}$ The scope of this substantive duty under the UNWCC has been articulated by Salman as follows:

${ }^{67}$ Case Relating to the Territorial Jurisdiction of International Commission of the River Oder (United Kingdom v Poland) PCIJ Series A No 23 Annex 3 (Order made on 20 August 1929), p. 27; supra Hungary v Slovakia note 56, para. 85; supra McIntyre note 63, p. 112; Magsig, B.-O., International Water Law and the Quest for Common Security (Routledge: Cheltenham, 2015), p. 49.

${ }^{68}$ Supra UNWCC note 65, Arts. 5, 6.

${ }^{69}$ Salman, S., 'Entry into force of the UN Watercourses Convention: why should it matter?' International Journal of Water Resources Development, 31:1, 4-16, p. 9. DOI: 10.1080/07900627.2014.952072.

${ }^{70}$ Supra UNWCC note 65, Art. 7. It has been clarified, however, that downstream countries can also harm upstream countries see e.g. Salman S., 'Downstream Riparians Can Also Harm Upstream Riparians: The Concept of Foreclosure of Future Uses' Water International (2010) Vol. 35(4) pp. 350-364.

${ }^{71}$ Supra Salman note 69.

${ }^{72}$ Supra UNWCC note 65, Arts. 20-26; Birnie, P., Boyle, A., \& Redgwell, C., International Law and the Environment (3rd ed., Cambridge University Press: Cambridge, 2009), pp. 535-582.

${ }^{73}$ McCaffrey, S., The Law of International Watercourses (2nd ed., Oxford University Press: Oxford, 1997), pp. 387-463; supra Magsig note 67. 
The Convention establishes a number of obligations on the watercourse states, including protection and preservation of ecosystems; prevention, reduction and control of pollution; introduction of alien or new species; and protection and preservation of the marine environment. A Statement of Understanding issued by the [UN General Sixth Committee] Working Group clarified that these provisions impose a due diligence standard on watercourse states. ${ }^{74}$

The UNWCC reconciles the principle of environmental protection with the principle of equitable utilisation on two grounds; the first, as enshrined under Article 5 itself, the equitable principle obliges watercourse states to take into account the interests of the watercourse States concerned, consistent the adequate protection of the watercourse.' And the second, as enshrined in Article 6 of the Convention, is that the realisation of the equitable utilisation must take into account factors such as socio-economic needs, impacts of water use, current and potential use and 'Conservation, protection, development and economy of use of the water resources of the watercourse and the costs of measures taken to that effect. ${ }^{, 75}$

However, such factors might be criticised for lacking empirical guidance and arguably for not objectively determinable. As Professor Dellapenna reflects upon, however,

Non-lawyers, particularly engineers and hydrologists, sometimes see in these catalogues of factors a poorly stated equation. By this view, if one simply fills in numerical values

\footnotetext{
${ }^{74}$ Supra Salman note 69, p. 10.

${ }^{75}$ Supra UNWCC note 65 , Art 6 (f); the full list of factors is:

(a) Geographic, hydrographic, hydrological, climatic, ecological and other factors of a natural character;

(b) The social and economic needs of the watercourse States concerned;

(c) The population dependent on the watercourse in each watercourse State;

(d) The effects of the use or uses of the watercourses in one watercourse State on other watercourse States;

(e) Existing and potential uses of the watercourse;

(f) Conservation, protection, development and economy of use of the water resources of the watercourse and the costs of measures taken to that effect;

(g) The availability of alternatives, of comparable value, to a particular planned or existing use.
} 
for each factor, one could somehow calculate each watercourse state's share of the water without reference to political or other non-quantitative variables. They simply ignore that the UN Convention... and the Helsinki Rules are legal documents that ultimately are addressed to judges. Judges make judgements, and in the English language, at least, the word judgement carries a strong connotation that the result is not dictated in any immediate sense by the factual and other inputs that the judge relies upon in exercising judgement. Any attempt to treat the list of relevant factors as an algorithm simply misses the point entirely. ${ }^{76}$

Article 6 of the UNWCC further reinforces this by clarifying that:

The weight to be given to each factor is to be determined by its importance in comparison with that of other relevant factors. In determining what is a reasonable and equitable use, all relevant factors are to be considered together and a conclusion reached on the basis of the whole. ${ }^{77}$

Hence, the principle of equitable utilisation serves as an umbrella and primary principle in applying distributive justice, being subordinated by the environmental protection and no significant harm principles. $^{78}$ Furthermore, the umbrella principle of international watercourses law and the factors necessary to determine equity are subject 'to consultations in a spirit of cooperation, ${ }^{79}$ which suggests that they can only be applied on a case-by-case basis depending on natural, man-made and other features of a watercourse. It follows from this that the equitable utilisation primary principle along with its subordinate norms and factors, as enshrined in the UNWCC, truly align to the notion of distributive justice for two simple reasons (i) it deals with the content and essence of the

76 Dellapenna, J. W., 'The customary international law of transboundary fresh waters', International Journal of Global Environmental Issues (2001) Volume 1, Issue 3-4, pp 264-305, p. 287.

${ }^{77}$ Supra UNWCC note 65, Art 6 (3). This needs to be read in conjunction with Art 10 of the Convention which suggests that no use has an inherent priority.

${ }^{78}$ Supra Salman note 71, p. 354.

${ }^{79}$ Supra UNWCC note 65, Art 6 (2). 
law the application of which impacts on states, communities and individuals; and (ii) the factors listed to determine the equitable principle further reinforce Franck's proposition that distributive justice should be determined in the context of relevant history and social context. Furthermore, the caveats and conditions to distributive justice fit into international watercourses law in that water resources are scarce, and competition over them has become fierce; there is no place for absolute or non-negotiable claims in the UNWCC as required in the fairness discourse too.

However, we cannot say with certainty that inequality is tolerated in international watercourses law. The UNWCC refers to 'existing and potential use' as one factor for determining equitable use, but it neither endorses nor rejects existing inequality of use among riparian states. Another notable difference is that while the international watercourses law principles and factors are legally endorsed standards, the fairness discourse sees distributive justice as moral notion. Such moral standards can, however, be integrated into legal instruments, as Franck himself acknowledges by referring to the terms of the (draft) UNWCC itself.

In contrast to distributive justice, the duty inter alia to cooperate, ${ }^{80}$ notify and consult, ${ }^{81}$ exchange of data and information, ${ }^{82}$ and dispute settlement provisions ${ }^{83}$ are procedural in character. ${ }^{84}$ The duty 'to enter into consultations' has been extended to managing 'an international watercourse, which may include the establishment of a joint management mechanism" ${ }^{85}$ and 'Planning the sustainable development of an international watercourse

\footnotetext{
${ }^{80}$ Supra UNWCC note 66, Art. 8. Art 25 (1) of the Convention provides: 'Watercourse States shall cooperate, where appropriate, to respond to needs or opportunities for regulation of the flow of the waters of an international watercourse.'

${ }^{81}$ Ibid, Arts. 12-18, 24.

${ }^{82}$ Ibid, Arts. 9, 11-19.

${ }^{83}$ Ibid.

${ }^{84}$ Supra McCaffrey note 73, pp. 464-481.

${ }^{85}$ Supra UNWCC note 66, Art 24 (1).
} 
and providing for the implementation of any plans adopted. ${ }^{86}$ Most importantly, the legal entitlement to participate in law making of watercourse states has been duly recognised under Article 4 (1) of the UNWCC; it reads:

Every watercourse State is entitled to participate in the negotiation of and to become a party to any watercourse agreement that applies to the entire international watercourse, as well as to participate in any relevant consultations.

This is extended to any agreement which 'applies only to a part of the watercourse or to a particular project' if the implementation of such an agreement may significantly affect a watercourse state's legal interests. ${ }^{87}$ Worthy of note is that Article 5 is also about equitable participation.

These and other procedural aspects of the UNWCC cover a range of activities -ranging from participation in law making to that of participation in institutional and formal processes and mechanism through which agreed legal standards are realised. This is very much in line with the procedural fairness conception of Franck. Unlike distributive justice, international watercourses law and Franck's procedural fairness concern legal (rather than moral) arrangements.

However, such categorisation can be misleading as some of the principles such as the equitable utilisation and participation, and the duty to take all appropriate measures to prevent significant harm, are both substantive and procedural in nature. ${ }^{88}$ Furthermore, as briefly mentioned earlier the application of the factors that are set out in Article 6 (2) of the UNWCC to determine equitable use require consultation and cooperation among

\footnotetext{
${ }^{86}$ Ibid, Art 24 (2) (a).

${ }^{87}$ Ibid, Art (4) (2). See also Art 25 (2) which provides: 'Unless otherwise agreed, watercourse States shall participate on an equitable basis in the construction and maintenance or defrayal of the costs of such regulation works as they may have agreed to undertake.'

${ }^{88}$ Supra McCaffrey note 73, p. 401; Rieu-Clarke, A., \& Pegram, G. 'Impacts on the International Architecture for Transboundary Waters', in, Loures, F. R., \& Rieu-Clarke, A., The UN Watercourses Convention in Force: Strengthening International Law for Transboundary Water Management (Routledge: Abingdon, 2103) pp. 67-76.
} 
concerned states. Similarly, the legal commitment on the management of watercourses has not only dealt with procedural matters but also with 'promoting the rational and optimal utilization, protection and control of the watercourse ${ }^{89}$ which forms part and parcel of the equitable utilisation and participation principle. This needs to be read with caution as the overlaps between distributive justice and procedural fairness do not fundamentally eliminate the natural boundary between a content and procedure of law.

Undoubtedly, customary international law governing shared watercourses, as represented by the UNWCC, ${ }^{90}$ provides the right platform to exhibit both the merits and challenges of the fairness discourse.

Despite the strong suggestion that some of the core rules of the field at issue constitute customary international law, and thus bind all states in respect of all international watercourses, the Convention has only been ratified by 36 States and applies to those who subscribe to it as far as treaty rights and duties are concerned. This adds to the complexity of applying the principles to all watercourses cases, in particular the procedural provisions that are key for a fair deal in using and protecting shared water courses as this work will demonstrate. Regardless, international watercourses law evidences that the notion of distributive justice can be found in special legal regimes of international law such as international watercourses law, which appear to challenge its unexplained rejection, including by the ICJ, as shown earlier.

It is of note that the UNWCC is a general instrument, and States parties to the Convention are thus allowed (and may also be encouraged) to enter into "watercourse agreements" 'which apply and adjust the provision of the present Convention to the characteristics and uses of a particular international watercourse or part thereof.' The implementation and

\footnotetext{
${ }^{89}$ Art 24 (2) (b).

${ }^{90}$ Salman, S., 'The Helsinki Rules, the UN Watercourses Convention and the Berlin Rules: Perspectives on International Water Law' Water Resources Development Vol. 23(4) pp. 625-640 (2007), pp. 625-640; supra Hungary v Slovakia note 55, para. 85.
} 
elaboration of the rules and principles enshrined in the UNWCC on a case-by-case basis would appear to be more appropriate, if not absolutely required; and in this article's case at sub basin-level. Basin-wide endeavours, as a basis, need consideration first.

\section{Relevance to an Emerging Nile Basin Legal Framework}

At present, none of Nile-basin countries are parties to the UNWCC which makes the search for [un]fairness in Nile water sharing difficult, if not impossible. This is because the Convention is not applicable to them without their consent. Countries of the basin do however rely on established principles of the law including the ones recognised in, and promoted by, the UNWCC as later examined, albeit selectively to substantiate their claims and counter-claims. ${ }^{91}$

More broadly, Nile basin-level initiatives have endorsed the aforementioned principles of international watercourses law. Negotiated within the Nile Basin Initiative $(\mathrm{NBI})^{92}$ framework, which is of transitional arrangement, ${ }^{93}$ the Cooperative Framework Agreement $(\mathrm{CFA})^{94}$ aims to promote cooperation, equality, optimal and sustainable use of Nile waters and sustainable development. ${ }^{95}$ Articles 8,10 and 12 of the CFA deal with the principles of information exchange on planned measures, data and information exchange and peaceful settlement of disputes respectively, which can be considered as dominantly procedural

\footnotetext{
${ }^{91}$ See sections on Colonial Treaties, post-1990 Instruments.

92 Salman, S., 'The Nile Basin Cooperative Framework Agreement: A Peacefully Unfolding African Spring?' Water International Vol. 38(1) pp. 17-29 (2013a), pp. 19-20. ${ }^{93} \mathrm{Ibid}$.

${ }^{94}$ Agreement on the Nile River Basin Cooperative Framework (CFA), May 2010, Retrieved from http://www.nilebasin.org/images/docs/CFA\%20-\%20English\%20\%20FrenchVersion.pdf. Seven countries agreed to the text to be opened for signature; six countries namely: Ethiopia, Kenya, Uganda, Burundi, Rwanda and Tanzania have signed the Agreement; Ethiopia, Tanzania and Rwanda ratified it; it requires six ratifications for its entry, and will replace the NBI when in full legal force. Retrieved from http://www.nilebasin.org/index.php/spotlight/99-cfa-overview.

${ }^{95}$ Ibid, Art. 1.
} 
commitments. The CFA also aims to establish a Nile River Basin Commission comprising Heads of State and Government, Council of Ministers, Technical Advisory Committee, Sectoral Advisory Committee and Secretariat to manage and administer effective cooperation among basin states including the sharing of information on planned measures. ${ }^{96}$

The substantive duties are similar, if not identical, to that of the UNWCC including the principles of equitable use,${ }^{97}$ preventing significant harm ${ }^{98}$ and protecting and conserving water resources. ${ }^{99}$ Interestingly, however, unlike the UNWCC, the CFA refers to the principles of 'subsidiarity' 100 and 'community of interest' 101 of Nile basin states; these are meant to promote an equitable share and sustainable use of water resources but also a sense of community in the sharing of the benefits and responsibilities relating to Nile waters and its ecosystem. Worthy of particular mention is the duty of basin States deduced from the principle of subsidiarity to 'allow all those within a State who will or may be affected by the project in that State to participate in an appropriate way in the planning and implementation process. ${ }^{102}$ Similar to the law in other river basins such as the Lake Victoria Basin, ${ }^{103}$ Danube, ${ }^{104}$ and the $\mathrm{EU}^{105}$ in general, this approach recognises the

\footnotetext{
${ }^{96}$ Ibid, Arts. 15-17, 8.

${ }^{97}$ Ibid, Art. 4.

${ }^{98}$ Ibid, Art. 5.

${ }^{99}$ Ibid, Art. 7.

${ }^{100}$ Ibid, Art. 3.

${ }^{101}$ Ibid, Art. 9.

${ }^{102} \mathrm{Ibid}$, Art 10 (a). This is followed from the main principle and commitment enshrined under Art. 3 (3) that 'development and protection of the Nile River Basin water resources is planned and implemented at the lowest appropriate level.'

103 Protocol for Sustainable Development of Lake Victoria Basin, 29 Nov. 2003, Art 3 (i) http://faolex.fao.org/docs/pdf/mul41042.pdf.

${ }^{104}$ Convention on the Cooperation for the Protection and Sustainable Use of the Danube River (Danube River Protection Convention), June 29, 1994 (entered into force Oct. 22, 1998), Art. Art 14 https://www.icpdr.org/main/icpdr/danube-river-protection-convention.

105 EU Water Framework Directive, 2000/60/EC, 23 October 2000. Para 46 states that 'To ensure the participation of the general public including users of water in the establishment and updating of river basin management plans, it is necessary to provide proper information of planned measures and to report on progress with their implementation with a view to the involvement of the general public before final decisions on the necessary measures are adopted.'
} 
participation (or/and the right to information) of non-state actors in the use and protection of river basin waters.

It can be argued that, although it does not explicitly deal with non-state actors' participation, the UNWCC contains similar principles to that of the CFA, as shown in articles 5, 6 and 7 as considered earlier; yet elements such as water contribution to a river basin as a factor to determine reasonable use $^{106}$ appears to be, justifiably ${ }^{107}$ or unjustifiably ${ }^{108}$ not explicitly included in the UNWCC. Furthermore, 'the extent and proportion of the drainage area in the territory of each Basin State' 109 has been listed as one of the criterion for equitable share of water resources of a basin under the CFA, but not the case in the UNWCC. According to this parameter those who have bigger drainage area within a river basin, which may not necessarily imply making more or less water contribution to a river basin, have an advantage over those who have smaller basin drainage areas, although as enshrined in CFA Art 4 (4) 'the weight to be given to each factor is to be determined by its importance in comparison with that of other relevant factors'. It is of note that the CFA does not claim to be exhaustive ${ }^{110}$ on its list of factors, which is broadly, but not identically, the case with the UNWCC. ${ }^{111}$ Notably, the GERD's DoPs boldly endorsed water contribution and the size or proportion of drainage area as factors to be taken into account in applying the principle of equitable use of Nile waters. ${ }^{112}$ Furthermore, 'the right of all Nile Basin States to reliable access to, and use of, the Nile River system for health, agriculture, livelihoods, production and the environment' was

\footnotetext{
${ }^{106}$ Ibid, Art. 4.

${ }^{107}$ Supra McIntyre note 63, pp. 182-183.

${ }^{108}$ The Helsinki Rules on the Uses of the Waters of International Rivers, International Law, August 1966, International Law Association, Art. V(b).

${ }^{109}$ Supra CFA note 94, Art 4 (i).

${ }^{110} \mathrm{Ibid}$, Art 4 (2) begins with 'including but not limited to the following', before listing the factors to be used for applying the equitable principle of water utilisation.

${ }^{111}$ Supra UNWCC note 65, Art 6, in comparison to the CFA begins with 'including' in listing the factors of the equitable principles.

${ }^{112}$ Supra DoPs note 12, sec. 3.2.
} 
introduced as part of the water security concept in the CFA; ${ }^{113}$ this concept is not explicitly mentioned in the UNWCC. The concept of water security was intended to bridge the differences between downstream and upstream countries ${ }^{114}$ and thus provide a symbol of fairness and equality. However, it was criticised for trying to introduce a non-legal concept $^{115}$ to a legal instrument dealing with a complex issue. Noteworthy is that water security appears to be derived from the famous concept of 'human security' which is by and large seen as a policy concept rather than a legal one. ${ }^{116}$

Arguably, the CFA is 'a peacefully unfolding African spring' ${ }^{117}$ for the following reasons. First, the Agreement, which comprises procedural and substantive principles, that are basically similar, but not identical, to the UNWCC, is an emerging legal development. Secondly, most Nile basin states subscribe to it and thus represent the hopes and fears of overwhelming majority of concerned parties. Finally, the CFA can be seen as declaratory of existing legal principles and rules in the field.

Yet, Egypt and Sudan are not on board for fear that their historic water rights will be affected and that the majority of participants will dominate decisions on projects. ${ }^{118}$ This is not only a bar to the emergence of basin-level effective cooperation ${ }^{119}$ but also detrimental to riparian states on matters of information exchange of planned measures via the Nile Basin Commission, although this does not equate to the duty of prior notification as

\footnotetext{
${ }^{113}$ Supra CFA note 94, Arts. 2 (f), 14.

${ }^{114}$ Supra Salman note 92, p. 21.

115 Mekonnen, D. Z., 'The Nile Basin Cooperative Framework Agreement Negotiations and the Adoption of a "Water Security" Paradigm: Flight into Obscurity or a Logical Cul-de-sac?" European Journal of International Law Vol. 21(2) pp. 421-440 (2010), doi: 10.1093/ejil/chq027

116 Yihdego, Z., 'Arms Control and Human Security: What Role for NSAs?', in, Ryngaert, C., \& Noortmann, M., Human Security and International Law: The Challenge of Non-State Actors (Intersentia: Cambridge, 2014) pp.135-174.

${ }^{117}$ Supra Salman note 92, pp. 17-29.

118 The Centre of Judicial Studies and Research of the State Council, 'Final Recommendations of the Conference on Nile Basin Agreements in Light of the Provisions of the International Law' African Perspectives Vol. 11(39) pp. 68-70 (2013), pp. 68-70.

${ }^{119}$ McKenzie, S. O., 'Egypt's Choice: From the Nile Basin Treaty to the Cooperative Framework Agreement, an International Legal Analysis' Transnational Law \& Contemporary Problems Vol. 21 (2012) http://papers.ssrn.com/sol3/papers.cfm?abstract id=2445962\#\#, pp. 571ff.
} 
enshrined in articles $12-18$ of the UNWCC. ${ }^{120}$ This led some to consider the CFA as untenable and called upon all concerned to negotiating a new legal regime for the Nile, ${ }^{121}$ although the main barrier for progress appeared to be lack of political will, an inability to compromise and low levels of mutual trust which may, or may not, be resolved through the CFA or a newly agreed legal framework.

Be that as it may, the CFA, either as an emerging treaty regime or a declaration of existing legal principles in international watercourses law, would be of vital use to address questions of fairness with respect to Nile water sharing. However, the unwillingness of Egypt and Sudan in endorsing the framework renders the initiative less relevant to the fairness discourse. This is not because the unfairness of the terms of the CFA but due to the fact that an agreement is one of the cardinal pre-requisites of a fair system. Resort to other relevant instruments, including Nile colonial-era treaties, thus, becomes imperative in search for the fairness of the GERD.

\title{
Colonial-era Treaties and the Fairness of the GERD
}

\author{
The Anglo-Ethiopian Treaty 1902 and the GERD
}

\footnotetext{
${ }^{120}$ Supra Salman note 92, p. 21.

${ }^{121}$ Kimenyi, M., \& Mbaku, J., Governing the Nile River Basin: The Search for a New Legal Regime (Brookings Institution Press: Arlington, 2015), pp. 83-89.
} 
The 1902 Nile treaty is amongst the key colonial treaties which were, and still are, invoked by Egypt $^{122}$ to oppose the construction of any project on major Nile tributaries stemming from Ethiopia. This Agreement signed by Ethiopia with colonial Britain (on behalf of Sudan) stipulated that Ethiopia must 'not construct or allow to be constructed any work across the Blue Nile, Lake Tana, or the Sobat, which would arrest the flow of their waters ${ }^{123}$ without consent from Britain and the Sudan.

Relating to the GERD, Shetewy ${ }^{124}$ understands the 1902 Treaty as 'Ethiopia's commitment to preserve Egypt's historical rights.' ${ }^{125}$ It is not clear why this Treaty is opposable to Ethiopia by Egypt, as the latter was not a party to that particular Treaty, although the Treaty should be read in conjunction with other treaties that were meant to protect Egyptian (and to some degree Sudan's) 'historic rights'. The 1929 Nile Treaty, which was concluded between colonial Britain (on behalf of Sudan) and Egypt, not only allocated 48 and $4 \mathrm{BCM}$ of Nile waters per annum for Egypt and Sudan respectively, but also went on to impose basin-wide duties, as enshrined in Paragraph 4 sub-(b) of the Treaty:

Except with the prior consent of the Egyptian Government, no irrigation works shall be undertaken nor electric generators installed along the Nile and its branches nor on the lakes from which they flow if these lakes are situated in Sudan or in countries under British administration which could jeopardize the interests of Egypt either by reducing the quantity of water flowing into Egypt or appreciably changing the date of its flow or causing its level to drop.

\footnotetext{
${ }^{122}$ See e.g. Supra Egyptian Perspectives note 6, p. 4. The 2014 document asserts that 'the conduct of the Ethiopian government is inconsistent with its obligations according to the 1902' Nile treaty. ${ }^{123}$ Nile Treaty 1902 -Blue Nile and Sobat Rivers (tributaries of the Nile) and Lake Tsana (Ethiopia and Sudan): Treaty between Ethiopia and the United Kingdom relative to the frontiers between the Anglo-Egyptian Sudan, Ethiopia and Eritrea, signed at Addis Ababa on 15 May 1902, Art III http://treaties.fco.gov.uk/docs/pdf/1902/TS0016.pdf.

${ }^{124}$ Shetewy, M. A., 'Legal Commitments Regulating the Establishment of Water Projects on International Rivers Application Study over the Nile Basin' African Perspectives Vol. 11(39) pp. 29-35 (2013).

${ }^{125}$ Ibid, pp. 34-35.
} 
Similarly, the bilateral Nile Treaty signed between Egypt and Sudan in 1959 divided the entire Nile water flow at 55.5 and 18.5 BCM per year respectively, excluding evaporation at the Aswan High Dam reservoir. The 1959 and the 1929 Nile Treaties pose several questions, including their fairness to the parties themselves. More specifically, the question of their fairness to Sudan (or Egypt) is not within the realm of this monograph; while their impact on perceived duties (and rights) of upstream countries, including on Ethiopia is certainly relevant here.

McCaffrey, ${ }^{126}$ citing Lauterpacht as an authority, sees the 1929 and the 1959 Treaties as legal engagements that are designed to share Nile waters that reach Sudan and Egypt; he further submits that these two treaties were meant neither to create obligations upon upstream countries nor were they endorsements of Egyptian 'prior apportionment.'

However, according to Shaw colonial boundaries are not subject to alteration (also known as uti possidetis juris), irrespective of 'their arbitrary and alien character.' ${ }^{127}$ Article iii of the 1902 Treaty was part of a boundary treaty. If one looks into the history of the provision, however, it is clear that it was separately negotiated for about three years to protect British Nile interests prior to its insertion onto the 1902 Treaty at a last minute. ${ }^{128}$ More vitally, as the article concerns restricting work on a transboundary river, rather than including a piece of land, lake or territorial waters to a state's sovereign territory, it is doubtful that the subject of Article iii belongs to boundary delimitation. ${ }^{129}$ There is no evidence that African states meant to include colonial laws and policies with respect to

\footnotetext{
${ }^{126}$ Supra McCaffrey note 73, p. 266.

${ }^{127}$ Shaw, M., 'The Heritage of States: The Principle of uti possidetis juris Today' British Yearbook of International Law Vol. 67(1) pp. 75-154 (1996), pp. 97, 104.

${ }^{128}$ Woldetsadik, T. W., International Watercourses Law in the Nile River Basin: Three States at a Crossroads (Routledge: Abingdon, 2013), p. 100; Garretson, A. H. 'The Nile Basin', in, Garretson, A. H., Hayton, R. D., \& Olmstead C. J., The Law of International Drainage Basins pp. 256-297 (Oceana: New York, 1967), p. 277.

${ }^{129}$ Supra Shaw note 127, p. 77.
} 
transboundary resources within the concept of 'respect of borders existing on achievement of independence.' 130

Although uti possidetis was widely endorsed by tribunals as a means of avoiding territorial disputes in Africa and elsewhere, ${ }^{131}$ its scope and nature was associated with the issue of acquisition of title to territory' and terra nullius (i.e. nobody's land) territories. ${ }^{132}$ Judge Yusuf argues strongly that: "none of the official documents of the OAU (Organisation of African Unity) or of its successor organization, the AU (the African Union), relating to African conflicts, territorial or boundary disputes, refers to or mentions in any manner the principle of uti possidetis juris ${ }^{1133}$ and it is therefore a legally different concept from what Art 4 of the AU constitutive Act prescribes.

Whatever the legal position of uti possidetis in Africa and elsewhere, its invocation with respect to shared watercourses' use, outside the context of boundary lines that are needed to limit 'territorial jurisdiction of states, ${ }^{134}$ is a misreading of the principle at best, or an attempt to evade state sovereignty, which embraces authority over their resources, at worst. Yet maintaining Nile status quo is imperative to the peace and stability of the regionchanging the current use of Nile waters without consent of all concerned is therefore not only illegitimate but also destabilising. ${ }^{135}$ Even when one endorses keeping the status quo

\footnotetext{
${ }^{130}$ Constitutive Act of the African Union, 11 July 2000 http://www.au.int/en/sites/default/files/ConstitutiveAct EN.pdf, Art. 4[b]; see also Cairo Declaration on Border Disputes among African States legitimising national borders inherited from colonial times (Cairo Declaration), OAU, 1964, paras. $1 \& 2$.

${ }^{131}$ Case Concerning the Frontier Dispute (Burkina Faso/Republic of Mali) Judgment ICJ 1986, p. 20.

132 Frontier Dispute (Burkina Faso/Niger) Separate Opinion of Judge Yusuf ICJ 2013 http://www.icj-cij.org/docket/files/149/17312.pdf, p. 137, para. 11.

${ }^{133}$ Frontier Dispute (Burkina Faso/Niger) Judgment ICJ Reports 2013, para. 10.

${ }^{134}$ Ratner, S., 'Drawing Better Line: UTI Possidetis and the Borders of New States' American Journal of International Law Vol. 90(4) pp. 590-624 (1996), p. 602.

${ }^{135}$ Lumumba, P. L. O., 'The Interpretation of the 1929 Treaty and its Legal Relevance and Implications for the Stability of the Region' African Sociological Review 11(1) pp. 10-24 (2007), pp. 7-18.
} 
argument the question remains whether such a justification should be followed at the expense of the basic rights of others on a shared watercourse. ${ }^{136}$

Furthermore, Article iii of the 1902 Nile treaty is seen as an invalid and non-ratified treaty by Ethiopia, ${ }^{137}$ but binding and applicable today by Egypt; ${ }^{138}$ arguably, the latter's position may be challenged or supported based upon the notion of fundamental change of circumstances (also known as rebus sic stantibus) as a ground to terminate or withdraw from a treaty obligation, as expressly recognised under article 62 of the Vienna Convention on the Law of Treaties 1969 (CVLT). ${ }^{139}$ This article has adopted stringent requirements such as a change of radical nature and the non-application of rebus sic stantibus to boundary treaties, which might support the argument that Ethiopia is not entitled to terminate or withdraw from Article iii obligations of the 1902 treaty. ${ }^{140}$

\footnotetext{
${ }^{136}$ Permanent sovereignty over natural resources, 14 December 1962, Resolution 1803 (XVII), United Nations General Assembly.

${ }^{137}$ Lie, J. H. S., 'Supporting the Nile Basin Initiative: A Political Analysis "Beyond the River"" Norwegian Institute of International Affairs (2010)

http://www.academia.edu/2243972/Supporting_the_Nile_Basin_Initiative_A_Political_Analysis_B eyond_the_River, p. 7.

${ }^{138}$ Supra Egyptian Perspective note 5.

${ }^{139}$ Vienna Convention on the law of treaties [VCLT] 1969, UNTS No. 18232. Art. 62 reads:

1. A fundamental change of circumstances which has occurred with regard to those existing at the time of the conclusion of a treaty, and which was not foreseen by the parties, may not be invoked as a ground for terminating or withdrawing from the treaty unless:

(a) The existence of those circumstances constituted an essential basis of the con sent of the parties to be bound by the treaty; and

(b) The effect of the change is radically to transform the extent of obligations still to be performed under the treaty.

2. A fundamental change of circumstances may not be invoked as a ground for terminating or withdrawing from a treaty:

(a) If the treaty establishes a boundary; or

(b) If the fundamental change is the result of a breach by the party invoking it either of an obligation under the treaty or of any other international obligation owed to any other party to the treaty.

3. If, under the foregoing paragraphs, a party may invoke a fundamental change of circumstances as a ground for terminating or withdrawing from a treaty it may also invoke the change as a ground for suspending the operation of the treaty.

${ }^{140}$ Salama, A., 'The Principle of Fundamental Change in Circumstances and its Impact on the Nile Basin Agreements' African Perspectives Vol. 11(39), pp. 36-40 (2013), pp. 36-40.
} 
Yet, decolonisation in Africa and elsewhere and the political and territorial changes in the Sudan ${ }^{141}$ and Ethiopia may arguably challenge the non-application of robus sic stantibus as a ground to invalidate Article iii of the 1902 treaty. What seems to be certain, is that the developments of the law in the field including the emerging CFA, ${ }^{142}$ the non-objection by Egypt and Sudan of the Tekeze dam ${ }^{143}$ built and completed in 2009 on one of Nile tributaries with an installed capacity of $300 \mathrm{mw}$ in electricity and supplies with electricity not only to Ethiopia but also to Sudan, and now the GERD and its acceptance by Sudan and Egypt, means that either the current situation is fundamentally different ${ }^{144}$ from what it was in 1902, and/or Egypt and Sudan may have wilfully withdrawn, by implication or otherwise, their claims, ${ }^{145}$ and thus, (article iii of) the 1902 Nile Treaty has been terminated, ${ }^{146}$ if not void ab initio. This is a particularly powerful argument as Sudan, on whose behalf Article iii was agreed, is now a strong backer of the GERD and other dams. ${ }^{147}$ For the reasons discussed earlier, furthermore, the argument that article iii of the treaty forms a boundary treaty in the context of Art 62 of the VCLT is without legal validity and might also amount to an abuse of robus sic stantibus. ${ }^{148}$ This is evident from the drafting history of Article 62 with reference to boundary treaties:

\footnotetext{
${ }^{141}$ Supra Woldetsadik note 128, p. 116.

${ }^{142}$ Tvedt, T., The River Nile in the Post-colonial Age: Conflict and Cooperation in the Nile Basin Countries (I B Tauris \& Co: London, 2009), p. 10; supra McCaffrey note 74, pp. 271-271.

143 'Ethiopia inaugurates Africa's first ever biggest power dam' (Sudan Tribune, 14 November, 2009).

${ }^{144}$ Supra VCLT note 139, Art 62(1)(a)-(b).

${ }^{145}$ Supra Tvedt note 142, pp. 10-11.

${ }^{146}$ Supra VCLT note 139, Art. 59(1).

147 Eleiba, A., 'Sudanese president backs Ethiopian dam ahead of Nile talks' (Ahramonline, 5 December, 2013) http://english.ahram.org.eg/NewsContent/2/8/88321/World/Region/Sudanesepresident-backs-Ethiopian-dam-ahead-of-Ni.aspx.

${ }_{148}$ When Art 62 of the CVLT was debated in the UN in 1968 Libya, amongst non-western European countries warned that the vague notion of fundamental change of circumstances can be abused by states. The USA, amongst others countries was very critical of the concept see Scbwelb, E., 'Fundamental Change of Circumstances', Comments on the 1968 Draft Convention on the Law of Treaties (Max-Planck-Institut für ausländisches öffentliches Recht und Völkerrecht, 1999) p.47 http://www.zaoerv.de/29 1969/29 1969 1 c 39 70.pdf (pp39-70).
} 
The 1963 Drafting Committee proposed the formula: "a treaty establishing a territorial settlement”, a phrase which like Waldock's (ILC Special Rapporteur on the VCLT) draft was intended to cover not only a transfer of territory itself but also ancillary rights arising from the transfer. This proved not to be acceptable to the majority which wished to avoid any reference to the grant of territorial rights and to limit the exception to treaties which either established a territorial boundary or actually transferred territory. ${ }^{149}$

This perhaps provides with a relatively clear indication on the limited scope of 'boundary treaties' in the context of the exclusion of their application to the robus sic stantibus-based invocation of terminating a treaty obligation.

Even so, and as outlined earlier, dozens of other Nile colonial-era treaties including the 1959 Nile Treaty concluded between Egypt and Sudan unambiguously aimed at the "full utilisation of the Nile waters"150 by both Egypt and Sudan. This Treaty was concluded despite the fact that Ethiopia served notice in 1957 that it would pursue unilateral development of the Nile water resources within its territory. ${ }^{151}$ By the same token, the 1929 Nile Treaty, which was committed by Great Britain on behalf of its east African colonies, was rejected not only by Ethiopia but also by Sudan, Tanzania, Burundi and Kenya. ${ }^{152}$ Some gave a grace period of two years from independence to negotiate on the fate of Nile and other colonial treaties entered into on their behalf; it was declared that

\footnotetext{
${ }^{149}$ Ibid, p. 55. The ILC did also clarify that 'By excepting treaties establishing a boundary from its (Art 62) scope the present article would not exclude the operation of the principle of selfdetermination in any case where the conditions for its legitimate operation existed' (ibid, p.58).

${ }^{150}$ United Arab Republic and Sudan Agreement (With Annexes) For the Full Utilization of the Nile Waters, 8 November 1959.

${ }^{151}$ Supra McCaffrey note 73, p. 269; Degefu, G. T., The Nile: Historical, Legal and Developmental Perspectives (Trafford Publishing: New York, 2003), p.99.

${ }^{152}$ Richard K., Paisley, K.R., \& Henshaw, W.T., 'Transboundary governance of the Nile River Basin: Past, present and future' Environmental Development (July 2013) Volume 7, p. 63, 59
} 
after the lapse of such a period the treaties are presumed to be terminated. This is often referred to as the Nyerere Doctrine ${ }^{153}$ as further explained in the forthcoming section.

The following points recap the discussion thus far: The 1902 Nile Treaty coupled with the 1929 and 1959 colonial-era treaties have been used by both downstream and upstream countries to defend their existing monopoly and demand for a fair share of the Nile waters respectively. ${ }^{154}$ However, their validity and current application have been seriously challenged. The 1959 Nile Treaty is unique in that it is not a colonial treaty per se, although as it was founded on the purpose and object of its predecessor, and a number Nile basin countries were still colonised when it was concluded, it can be said that it is closer to Nile colonial treaties than contemporary international watercourses law. Even if these treaties are said to still be applicable, the question of their fairness remains. The next section therefore analyses the fairness of these treaties and their implications for the GERD, in the light of what has been considered so far and other issues of treaty law such as the law of succession.

\section{The GERD's Fairness in the Eyes of Colonial Treaties}

As Franck diligently put it:

\footnotetext{
${ }^{153}$ Okoth-Owiro, A., 'State Succession and International Treaty Commitments: A Case Study of the Nile Water Treaties' (Occasional Paper, East Africa \# 9, 2004), pp.13-21 http://www.kas.de/wf/doc/kas 6306-544-1-30.pdf; as considered later, the Nyerere doctrine was named after the position of the first prime minister of independent Tanganyika (later Tanzania), Julius Nyerere on the Nile issue; he took the position that Tanganyika is not bound by Nile colonial treaties unless the obligations form part of customary international law. Kasimbazi, E.B., 'The impact of colonial agreements on the regulation of the waters of the River Nile' Water International, 35:6, 718-732 ((2010) DOI:10.1080/02508060.2010.533642; supra Salman note 92, p. 18.

${ }^{154}$ Supra McCaffrey note 73, p. 270.
} 
Achieving a shared perception of fairness is much harder than thinking up a formula, but no formula can legitimate a mandatory regime of allocation which is not perceived as fair by those whose conduct it is meant to regulate. In this lies the existential opportunity, the pragmatic imperative. Fairness is the only basis for allocation on which 'everyone' is likely to agree. ${ }^{155}$

The implications of colonial treaties for the fairness debate and dilemma are now analysed with such a powerful quote in mind. Procedurally, Ethiopia is arguably bound by the 1902 Nile Treaty. Ethiopia was an independent sovereign state who 'agreed' not to 'arrest' Nile waters or construct any projects on the tributaries of the River and thus bound by the Treaty. ${ }^{156}$ However, the circumstances of concluding that Treaty, including its ambiguity, subsequent rejection and non-ratification by Ethiopia rendered it void from the outset. ${ }^{157}$ Most importantly, the British Empire, as a party to that particular Treaty ceased to exist decades ago, thus invoking it today against the GERD is procedurally flawed.

Egypt and Sudan might argue that they are justified in invoking the 1902 Treaty to oppose the GERD as successors of colonial Britain, ${ }^{158}$ which is supported by the 'continuity' doctrine of legal commitments. ${ }^{159}$ The law of treaty succession ${ }^{160}$ appears to be clear that all (bilateral) treaties, especially those which lack universal appeal, are not assumed to be succeeded by independent or newly created states, a position supported by the 'clean state' or 'non-devolution' doctrine. ${ }^{161}$ Most, if not all, Nile basin countries, as former colonies of

\footnotetext{
155 Supra Franck note 28, p. 13.

${ }^{156} \mathrm{Aal}, \mathrm{M}$. S., 'Equitable and Reasonable Utilization of International Rivers in the UN Convention with a Particular Reference to the River Nile' African Perspectives Vol. 11(39) pp. 22-28 (2013), p. 27.

${ }^{157}$ (See supra [Anglo-Ethiopia Treaty] sec).

158 Abulwafa, A., 'Commitment of International Conventions on the River Nile' African Perspectives Vol. 11(39) pp. 7-13 (2013) http://www.sis.gov.eg/newvr/afaken39/3.pdf, pp. 7-13

${ }^{159}$ Craven, M. C. R., 'The Problem of State Succession and the Identity of States under International Law' European Journal of International Law Vol. 9 pp. 142-162 (1998), p. 147

${ }^{160}$ Supra VCLT note 139, Art. 16.

${ }^{161}$ Maluwa, T., International Law in Post-Colonial Africa (Martinus Nijhoff: Leiden, 1999), p. 69; Leb, C. \& Tignino, M., 'State Succession to Water Treaties: Uncertainties and Extremes', in, de
} 
Britain, rejected Nile colonial-treaties, which comprise the Sudan. ${ }^{162}$ In particular, the 1961 Declaration of Tanganyika on succession of the 1929 Treaty articulates both the rejection of that treaty imposed on it and on others and the need for starting a fresh process based upon negotiation, reciprocity and equity - it reads as below:

The Government of Tanganyika has come to the conclusion that the provisions of the 1929 Agreement purporting to apply to the countries 'under British Administration' are not binding on Tanganyika. At the same time, however, and recognizing the importance of the waters of the Nile that have their source in Lake Victoria to the Government and peoples of all the riparian states, the Government of Tanganyika is willing to enter into discussions with other interested Governments at the appropriate time, with a view to formulating and agreeing on measures for the regulation and division of the waters in a manner that is just and equitable to all riparian states and of the greatest benefits to all their peoples. ${ }^{163}$

This position, which is elaborated in procedural and time period terms, as discussed earlier, was followed by other countries that were former colonies, and is a strong evidence of the 'clean state' doctrine of state succession in action. This doctrine may not apply, however, to (independent) Ethiopia regarding the 1902 Nile Treaty because it was not colonised like the others. Yet the unevenness of the deal between a mighty colonial power and a country under exigent threat from different colonial powers makes such an argument untenable. ${ }^{164}$ Conversely, Sudan on whose behalf the 1902 Treaty was concluded was a colony of Britain, and thus a beneficiary of the clean state doctrine, an entitlement which was exercised by Sudan against the 1929 Nile Treaty. ${ }^{165}$ Whether Sudan will formally and

Chazournes, L. B., Leb, C., \& Tignino, M., International Law and Freshwater: The Multiple Challenges pp. 421-444 (Edward: Cheltenham, 2013), p. 425.

${ }^{162}$ Supra McCaffrey note 73, p. 270.

${ }^{163}$ As quoted in supra Mekonnen note 115, p. 434.

${ }^{164}$ Supra Degefu note 151, p. 99.

${ }^{165}$ Supra McCaffrey note 73, p. 269. 
expressly abandon colonial treaties as a legal basis for its Nile water entitlement remains to be seen. ${ }^{166}$ If Sudan expressly or impliedly renounces the application of the 1902 Nile Treaty, however, it will be apparent that Egypt will not have a legitimate ground to rely on that Treaty for purposes of objecting to current or future projects upstream, including the GERD. It may be said that Egypt (and Sudan) have impliedly renounced the 1902 Nile treaty by officially endorsing the GERD; however, this contradiction will remain unless the 1902 Treaty is expressly denounced by Egypt as a legal ground to question projects upstream. It is unlikely that the 1959 Nile Treaty is relevant to the law of state succession involving other Nile riparians, arguably excepting South Sudan. It is of note that the law of treaty succession was not meant to retain illegal earlier treaties. ${ }^{167}$

In a nutshell, these are largely procedural questions ranging from rules of treaty making to that of state succession (and uti possidetis), the primary legal basis of which has been the 1902 Nile Treaty. However, this 104 years old Treaty was not procedurally fair, similar to the rest of Nile colonial treaties, and therefore does not provide a sound legal basis to reject the GERD as procedurally unfair; this does not inevitably render Article iii of the Treaty substantively unfair and the GERD fair.

Substantively, it is often maintained by some authors aiming to protect the historic use 'rights' of Egypt in particular to which the Nile is seen as lifeblood ${ }^{168}$ that the 1902 and the 1929 and 1959 Nile treaties are fair. The desert State's population heavily rely on this river for drinking, fishing, agriculture, hydropower and tourism. However, it is also fair to say that Nile colonial-era treaties including the 1902 Treaty, like other colonial treaties, were instigated by self-interest of colonial powers rather than shared interest of the community of Nile riparian states. For this reason, and despite the claim of pursuing 'a civilising

\footnotetext{
166 Supra Salman note 92.

${ }^{167}$ Supra Ratner note 134, p.600. Supra Hungary v. Slovakia note 55.

${ }^{168}$ E.g. supra, note 156, p. 27.
} 
mission', such colonial treaties have been 'discontinued in international law' as substantively flawed and discriminatory treaties. ${ }^{169}$ Importantly, the treaties at issue conflict with the right to self-determination of peoples in upstream countries and their entitlement to fair use and utilisation of the river's resources, while their tributaries contribute every drop of Nile waters, and thus defeat the notion of distributive justice. ${ }^{170}$

It appears that the British Empire recognised such injustice as early as the 1950s, and began to question the absolute ownership of the Nile by downstream countries, particularly by Egypt. The 1959 UK declaration on the subject submits that:

the territories of British East Africa will need for their development more water than they at present use and will wish their claims for more water to be recognised by other states concerned. Moreover, they will find it difficult to press ahead with their own development until they know what new works downstream States will require on the headwaters within British East African Territory. For this reason, the United Kingdom Government would welcome an early settlement of the whole Nile waters question. ${ }^{171}$

This declaration only concerns Uganda, Kenya and Tanganyika, all former colonies of the British Empire, but Ethiopia as a legitimate stakeholder in matters of Nile waters was also publicly referred to by British authorities as early as 1956. For example, MP James Johnson (of Rugby), stressed in parliamentary debate held in May 18, 1956 that the enormous significance the future establishment of a Nile Valley Authority could have for people, black and white alike, in Ethiopia, Uganda, Tanganyika and Kenya. It is a

\footnotetext{
${ }^{169}$ Boyle, A., \& Chinkin, C., The Making of International Law (Oxford University Press: Oxford, 2009), pp. 28-29.

170 Yihdego, Z., The Blue Nile dam controversy in the eyes of international law, Global Water Forum, http://www.globalwaterforum.org/2013/06/18/the-blue-nile-dam-controversy-in-the-eyesof-international-law/.

${ }^{171}$ Garretson, A. H., 'The Nile River System' Proceedings of the American Society of International Law Vol. 54 pp.136-163 (1960), p.143.
} 
bold and imaginative project. The conservation of the waters of the Nile opens up an exciting future for the people of those parts. ${ }^{172}$

Although there is no evidence that there was a trace of official policy to address the interests of Ethiopia with respect to Nile waters, the aforementioned quote shows that there was some discussion about, and recognition of, Ethiopia's interest in British establishments.

To sum-up, both the downstream and upstream sides of the equation believe, or claimed to have believed, in fair use of Nile waters. Their views on the fairness of relevant colonial treaties reflect this - the treaties considered above are claimed to be fair to protect historic and prior water use, while unfair from upstream countries' perspectives. This evidences the fairness dilemma in sharing and protecting Nile water resources as the very same treaties are often relied upon to make a fair use and protect existing use of Nile waters. Hence, the treaties at issue are not that helpful to judge the (un)fairness of the GERD as fairness is about agreeing on fundamental principles that duly take into account the legal rights and interests of all parties. The two post-1990 Nile framework instruments provide better insights into the fairness of the GERD, and will therefore be considered next.

\section{Post-1990 Nile Instruments: a way out from the fairness dilemma?}

\section{The 1993 Framework Instrument}

Some legal and political context to this section may be useful here. The Framework for

General Co-operation between the Arab Republic of Egypt and Ethiopia ${ }^{173}$ (Framework

\footnotetext{
${ }^{172}$ Nile Waters: HC Deb 18 May 1956 vol 552 cc2375-412, sec 2395, italics added. http://hansard.millbanksystems.com/commons/1956/may/18/nile-waters\#column 2395.
} 
Instrument) was signed by presidents Hosni Mubarak of Egypt and Meles Zenawi of Ethiopia in July 1993 in Cairo. In Ethiopia it was a transitional legal and political era which was led by a Transitional Government, established under the Transitional Period Charter of Ethiopia $1991 .^{174}$ In contrast, although with its own serious internal challenges including Islamic extremism, repression and economic crisis, Egypt was under the leadership of a long serving president and (relatively) strong inter alia in its diplomatic, institutional and human capacity ${ }^{175}$ that are crucial to promote a state's legal and political interests. As the detailed discussion will reveal, it is not clear whether the Framework Instrument was signed in good faith (also known as bona fides) by the parties to it as required by international (watercourses) law. ${ }^{176}$ Moreover, it is not clear whether it was a hastily or a well-thought-out negotiated political/legal undertaking.

Nevertheless, the Framework Instrument duly signed by the two heads of State recognised the need for realising 'their full economic and resource potential' and underlined that both have 'mutual interest' in the Nile basin. ${ }^{177}$ The principles of 'good neighbourliness', 'peaceful settlement of disputes', 'non-interference' in their internal affairs', 'mutual trust and understanding', and 'promoting economic and political interests', including regional stability have been laid out in the Instrument. ${ }^{178}$ These founding principles were followed by substantive and procedural provisions. The latter includes 'creating appropriate

\footnotetext{
${ }^{173}$ Framework for General Co-operation between the Arab Republic of Egypt and Ethiopia, 1 July 1993 http://gis.nacse.org/tfdd/tfdddocs/521ENG.pdf.

174 Negarit Gazeta, 1991-07-22, Vol. 50, No. 1, pp. 1-5.

175 Hashim, A., 'The Egyptian Military, Part Two: From Mubarak Onward' Middle East Policy Council, Winter 2011, Volume XVIII, Number 4.

${ }^{176}$ Supra UNWCC note 66, Art 3 (5). Although the Convention was not adopted then the principle of good faith is regarded as a general principle of law and perhaps as customary international law see Separate opinion of Judge Bedjaoui supra Hungary v. Slovakia note 56, para 60 http://www.icj-cij.org/docket/files/92/7385.pdf.

${ }_{177}$ Ibid, preamble.

${ }^{178}$ Ibid, Arts. 1-3.
} 
mechanisms ${ }^{\text {'179 }}$ for cooperation. Article 4 of the framework document further spelt out the following:

The two Parties agree that the issue of the use of the Nile waters shall be worked out in detail, through discussions by experts from both sides, on the basis of the rules and principles of international law.

This article appears to contain both procedural and substantive elements. The stipulation that the use of water is subject to detailed expert study appears to be a procedural commitment which ties into the notions of cooperation, creating mechanisms through which the two countries and their experts will work together and promote basin-level cooperation as reaffirmed under Article 8 of the framework.

Likewise, the substantive dimension of Article 4 broadly, but vaguely, refers to 'rules and principles of international law.' Interpreting this phrase can lead to two varied views: on the one hand, the rules codified in colonial treaties can be interpreted as relevant rules and 'principles'; on the other hand, as in previous sections, customary international watercourses law advocates the principle inter alia of equitable and reasonable utilisation and participation, rather than a monopoly of use and decision making.

However, while the instrument does not specifically refer to such principle, Article 5 endorsed the duty 'to refrain from engaging in any activity related to the Nile matters that may cause appreciable harm to the interests of the other party'. Oddly, this subordinate rule to the principle is there while the customary international law umbrella principle, equitable use and participation, ${ }^{180}$ is absent from the instrument. Worthy of mention is that Article 7 (1) of the UNWCC refers to the duty to 'take all appropriate measures to prevent the causing of significant harm to other watercourse States' rather than 'to refrain from

\footnotetext{
${ }^{179}$ Ibid, Arts 7, 4.

${ }^{180}$ Salman, S., 'The World Bank Policy for Projects on International Waterways: An Historical and Legal Analysis' (World Bank, 2009) pp.95-96
} 
engaging in any activities...', which arguably makes the latter a more prohibitive and restrictive undertaking compared to the 1993 instrument, when read in the light of the deliberate or unintended omission of the customary international law principle of equitable and reasonable use from the text. Yet, conserving and protecting Nile waters with the aim of enhancing the 'volume of flow and reduce the loss of Nile waters through comprehensive and integrated development schemes' was incorporated under Article 6 of the framework.

This instrument was hailed by some as 'the nascent regime change in the Nile Basin', ${ }^{181}$ which helped in 'moving them more recently toward more cooperative behaviour; ${ }^{182}$ given the history of rigid water sharing claims in the basin this observation was not without merit. However, it is doubtful that, following the adoption of this instrument either Egypt was committed to abandoning its historic 'right' claims, or Ethiopia abandoned its equitable use claims.

The 1993 instrument is a written commitment signed by two heads of State, which might fulfil the definition of a treaty under Article 2 (1) (a) of the VCLT 1969. It was also later registered with the UN Secretariat. ${ }^{183}$ To Mohamod Abdo, ${ }^{184}$ the agreement 'merely represents the first attempt by the two states to come together, and does not have a binding effect. It is no more than the heralding of a new era of improved relations between the two states with regard to the water of the Nile.' ${ }^{185}$ To Shetewy, in contrast, 'Ethiopia had

${ }^{181}$ Brunnee, J., Toope, S. J., 'The Changing Nile Basin Regime: Does Law Matter?' Harvard International Law Journal Vol. 43(1) pp. 105-159 (2002)., pp. 108-109.

${ }^{182}$ Ibid, p. 110.

${ }^{183}$ Framework for general cooperation between the Arab Republic of Egypt and Ethiopia 1993, UNTS, Vol. 2693, No. 47816

https://treaties.un.org/Pages/showDetails.aspx?objid=08000002802a6733.

${ }^{184}$ Abdo, M., 'The Nile Question: The Accords on the Water of the Nile and Their Implications on Cooperative Schemes in the Basin' Perceptions Summer (2004) pp. 45-57 (2004) http://sam.gov.tr/wp-content/uploads/2012/01/4.-Mohammed-Abdo.pdf.

${ }^{185}$ Ibid, p. 51. 
ratified' the Agreement and 'pledged not to violate Egypt's historical rights.' ${ }^{186}$ It is not clear whether the word 'ratified' was used here by Shetewy in its technical and legal sense but a president cannot ratify a treaty in accordance with the Ethiopian Constitution.

As per Article 14 of the VCLT, the binding nature of such 'less formal agreements' depends on the intention of the parties to be bound by them under international law. ${ }^{187}$ The International Court of Justice (ICJ) applies an 'objective test' in determining whether a document gives rise to legal rights and duties under international law, taking into account 'its actual terms and ... the particular circumstances in which it was drawn up.' ${ }^{188}$ In the present case the formulation of an intention of both sides can hardly be deduced from the text to evidently support or reject either Shetewy's or Abdo's arguments. However, Abdo's argument makes sense in that, unlike the 2015 DoPs, the commitment at issue lacks specific rights and duties including some references to dispute resolution.

Yet the instrument was registered with the UN in $2010,{ }^{189}$ in accordance with Article 102(1) of the UN Charter, which states that 'every treaty and every international agreement entered into by any Member of the United Nations...shall as soon as possible be registered with the Secretariat and published by it. ${ }^{, 190}$ Unlike the League of Nations Covenant, ${ }^{191}$ however, non-registration of an agreement does not decide its binding or non-binding nature. ${ }^{192}$ The ICJ and other UN organs do not consider registration of an instrument when dealing with cases involving agreements concluded between states. ${ }^{193}$ It follows that the Secretariat generally registers an agreement when submitted to it by any one of the parties,

\footnotetext{
${ }^{186}$ Supra Shetewy note 124, p. 35.

${ }^{187}$ Crawford, J., Brownlie's Principles of Public International Law (8 ed., Oxford University Press: Oxford, 2012), pp. 372-273.

${ }^{188}$ Aegean Sea Continental Shelf Case (Greece v Turkey) ICJ Repts 1978, p. 3, para. 39.

${ }^{189}$ Supra 1993 Framework Instrument note 183.

190 (italics added).

191 (League of Nations Covenant, Art 18).

${ }^{192}$ Charter of the United Nations, 24 October 1945, Art. 102-Sub-(2).

${ }^{193}$ Martens, E., 'Article 102, in, Simma, B., et al, The United Nations Charter: Commentary 3rd ed. Volume 2 pp. 2098-2109 (Oxford University Press: Oxford, 2012), p. 2109.
} 
without making a judgement on the nature of that instrument. ${ }^{194}$ In light of this the registration of the 1993 instrument by the UN upon Egypt's request may give rise to two viewpoints. On the one hand, Egypt meant it to be a binding commitment. The fact that it was relied upon to oppose the GERD reinforces this position. ${ }^{195}$ On the other hand, Ethiopia neither backed (nor opposed) its registration with the UN nor has it ratified it before its parliament. The move to register the instrument by Egypt after the lapse of 17 years arguably poses questions of good faith and might not be in compliance with the 'as soon as possible' precondition of Article 102 (1) of the Charter. Even if it was registered in good faith there was no shared understanding between the parties on the legal character of the instrument.

Assuming that it was binding, it is highly unlikely that it gives rise to specific legal duties and entitlements ${ }^{196}$ as it was broadly construed and not supported by follow-up commitments. Again, if one concludes that it creates legal obligations, it follows that both sides might have violated it as further considered below. Worthy of note is the point that framework agreements must not be confused with framework conventions such as the United Nations Framework Convention on Climate Change 1992. These are legally binding frameworks, ${ }^{197}$ whereas framework agreements do not normally require formal ratification, ${ }^{198}$ the binding nature of which can only be determined on a case-by-case-basis.

\footnotetext{
${ }^{194}$ Ibid.

${ }^{195}$ Supra Egypt's Perspective note 5.

${ }^{196}$ Hollis, D. B., The Oxford Guide to Treaties Edited by Bibliographic Information (Oxford University Press: Oxford, 2012) p. 32.

197 Hossain, K., 'The Environmental Law-Making Process', in, Alam, S., et al., Routledge Handbook of International Environmental Law pp. 61-76 (Routledge: Abingdon, 2013), p. 70. Arguably, however, the 'adoption, application, modification, interpretation and termination of treaties are, in principle, applicable to framework agreements and their protocols' as per MatzLück, N., 'Framework Conventions as a Regulatory Tool' Goettingen Journal of International Law 1 (2009) 3, 439-458, p. 442. It ought to be noted that the author appears to use the phrase 'framework convention' as synonymous to a 'framework agreement.'

${ }^{198}$ Ulfstein, G., 'Reweaving the Fabric of International Law? Patters of Consent in Environmental Framework Agreements', in, Wolfrum, R., Roben, V., Developments of International Law in Treaty Making pp. 145-154 (Springer: Heidelberg, 2005), pp. 145-148.
} 
To recap, the 1993 instrument, different from what some hoped for, was an unfinished and vague law-making endeavour, which is selectively relied upon later by the parties to blame each other. Despite the ambiguity over its hard or soft law nature it was an important commitment and part of a law-making process $;^{199}$ it has endorsed general principles, aspirations and positive spirit of cooperation, which arguably and fundamentally differ from colonial-era Nile treaties and thus impact upon the fairness of the GERD. This assertion requires further consideration but prior to doing so, the March 2015 DoPs has been considered in order to engage with the fairness or otherwise of the two post-1990 instruments more generally, and with the most current one more specifically.

\section{The Declaration of Principles 2015}

The DoPs, by contrast to the 1993 instrument, is a tripartite commitment signed by Egypt, Ethiopia and Sudan in March 5, 2015. It provides a relatively detailed insight into the opportunities and challenges of the sharing of water resources in the Eastern Nile basin. ${ }^{200}$ The interest here is to look into the connotations of the instrument to the fairness of the GERD. The general and specific principles on which the Declaration is founded are briefly articulated first to help understand the fairness analysis.

The DoPs aspires to promote the 'common interest' of, and cooperation among, the signatories, based, inter alia, on 'sovereign equality', 'principles of international law', 'good faith', 'optimal use' and 'protection of the river.' ${ }^{201}$ The 'Principle of Development, Regional Integration and Sustainability' further recognised that:

\footnotetext{
${ }^{199}$ Supra Boyle \& Chinkin, note 169, pp. 211-14; Van Hoof, G. J. H., Rethinking the Sources of International Law (Kluwer: Berlin, 1983), pp. 187-189.

${ }^{200}$ Supra Salman note 15.

${ }^{201}$ Supra DoPs note 12, Arts. i, ix.
} 
The purpose of the GERD is for power generation, to contribute to economic development, promotion of transboundary cooperation and regional integration through generation of sustainable development and reliable clean energy supply. ${ }^{202}$

This is reinforced by the principles of equitable use and no significant harm as enshrined in articles iii [a-j] and iv respectively. The content of both principles is almost identical with the UNWCC and the CFA notwithstanding some differences in the factors that are required to apply the equitable use principle. While the aspirations and some of the principles are to be found in the 1993 Nile instrument, the DoPs took pains to not only recognise a mega dam by a Nile upstream country but also to endorse fundamental principles of international watercourses law. ${ }^{203}$

These general principles are followed by a series of specific principles and practical commitments among which is the principle of dam safety, ${ }^{204}$ which aims to prevent significant harm on Sudan and Egypt the distinct standing of which (from the nosignificant harm rule) is debatable. Worthy of noting is that while the Berlin Rules ${ }^{205}$ and some domestic legislation ${ }^{206}$ regard dam safety as a normative rule, the Helsinki Rules, and most importantly the UNWCC, do not explicitly mention dam safety. The World Commission on Dams, stressing building dams as a sovereign matter, recommended that the issue of dam building be handled within existing principles and rules of international watercourses law including the equitable use, no significant harm, good faith negotiations,

\footnotetext{
${ }^{202}$ Ibid, Art. Ii.

${ }^{203}$ Ibid, sec. 3.3.

${ }^{204}$ Ibid, Art. Viii.

${ }^{205}$ Ibid, Arts. 32, 34.

${ }^{206}$ See e.g. Act to amend the National Dam Safety Program Act to reauthorize the national dam safety program, and for other purposes, 22 December 2006, Public Law 109-460 [USA] https://www.congress.gov/109/plaws/publ460/PLAW-109publ460.pdf; National Water Act, 6 August 1998, Act No. 36 [South Africa] http://www.acts.co.za/national-water-act-1998/, chapter 12.
} 
cooperation and the use of an expert panel for addressing concerns when required. ${ }^{207}$ From this and whether or not dam safety is a (distinct) legal, as opposed to a policy, principle of international watercourses law, there is no doubt that it is a crucial part of the due diligence or the duty to take measures to prevent significant harm.

Of course, if an emergency ${ }^{208}$ arises relating to a dam in a shared watercourse, as per Article 28 (3) of the UNWCC

A watercourse State within whose territory an emergency originates shall, in cooperation with potentially affected States and, where appropriate, competent international organisations, immediately take all practicable measures necessitated by the circumstances to prevent, mitigate and eliminate harmful effects of the emergency.

This appears to reiterate the duties enshrined in Article 7 (2) of the UNWCC, when a significant harm has been caused, as considered early. It might be presumed that natural or man-made emergencies cause, or most likely to cause, significant harm, if they occur; it is, therefore, natural to expect a swift action to prevent human, socio-economic and natural disaster.

The other principle the DoPs has adopted is "the principle to cooperate on the First Filling and Operation of the Dam. ${ }^{209}$ This is accompanied by institutional and implementation mechanisms which include the establishment and use of national, joint and international bodies such as the IPoE and consultancy firms. Such technical and institutional

207 Salman, S., "Dams, International Rivers, and Riparian States: An Analysis of the Recommendations of the World Commission on Dams." American University International Law Review 16, no. 6 (2001): 1477-1505. See pp 1487-1503. For more discussion on human health and safety issues in the context of the primacy of the rule of significant harm see Supra Dellapenna note 77, p.283.

${ }^{208}$ As per the UNWCC (supra note 65), Art 28 (1), 'emergency' means a situation that causes or poses an imminent threat of causing, serious harm to watercourse states or other states and that results suddenly from natural causes, such as floods, the breaking up of ice, landslides or earthquakes, or from human conduct, such as industrial accidents.'

${ }^{209}$ Supra DoPs note 12, Art. V. 
mechanisms are indeed vital to effective cooperation in matters of transboundary rivers. ${ }^{210}$ Information and data exchange has also been considered as a principle which ought to be honoured 'in good faith and in a timely manner. ${ }^{211}$ However, the principle of confidence building through electric power sharing, with priority of power supply being given to Sudan and Egypt, ${ }^{212}$ appears to be alien to the UNWCC, the Helsinki and Berlin Rules and the CFA, but not necessarily to transboundary water management frameworks. ${ }^{213}$

Before looking at the connotations of the principles enshrined in the DoPs to the fairness question, the following general points recap what has been considered thus far. First, the DoPs is founded on current legal thinking in the field to a greater extent than the 1993 instrument, which makes it distinct from old Nile treaties. ${ }^{214}$ Such current principles are translated into detailed commitments of cooperation, including on dam safety, filling and operation and energy/benefit sharing. Finally, the principles at issue appear to have been formulated in such a way to apply to the entire Nile as far as the use of Nile waters within respective territories of the parties is concerned. However, the legal status of the DoPs is unclear.

The binding nature of the DoPs depends on the content, wording and the intention of the parties to it. ${ }^{215}$ Generally, it is a question of whether a written declaration made by two or more states 'generate a normative commitment - a shared expectation of future behaviour whether in terms of a change from the status quo or a continuation of existing behaviour. ${ }^{216}$ Even if a declaration does not constitute a binding treaty, it can reaffirm

\footnotetext{
${ }^{210}$ Supra McCaffrey note 73, p. 511.

${ }^{211}$ Supra DoPs, note 12, Art. Vii.

${ }^{212}$ Ibid, Art.vi.

${ }^{213}$ Allan, J. A., \& Mirumachi, N., 'Why Negotiate? Asymmetric Endowments, Asymmetric Power and the Invisible Nexus of Water, Trade and Power That Bring Apparent Water Security', in, Earle, A., Jägerskog, A., \& Öjendal, J., Transboundary Water Management: Principles and Practice pp. 13-26 (Earthscan: London, 2010), p. 22.

${ }^{214}$ Supra DoPs note 12.

${ }^{215}$ Ibid.

${ }^{216}$ Supra Hollis note 196, p.20.
} 
established principles and customary rules of international law, and thus be declaratory of legal duties and rights of states. Examples of such instruments include the Universal Declaration on Human Rights $1948^{217}$ and the Declaration on the Friendly Relations between States $1970,{ }^{218}$ both of which are widely regarded as authoritative sources or an affirmation of existing law. ${ }^{219}$ Similarly, bilateral or trilateral declarations may be legally binding, depending on their details and circumstances of conclusion. ${ }^{220}$ The ICJ in the Cameroon/Nigeria ${ }^{221} 2002$ boundary delimitation case endorsed a declaration as a legal instrument despite some technical shortcomings. ${ }^{222}$

In this context, three opposing arguments are considered with respect to the legal character of the GERD's DoPs. The first argues that the DoPs, similar, if not identical, to the 1993 instrument, is a soft law (which is not binding) rather than a hard law (which is legally binding) instrument. The absence of formal phrases including a clause on entry into force, ratification and deposit as stipulated in Art 24 (4) of the VCLT can be cited as evidence to support this. The Ethiopian Parliament has not ratified the Declaration, which is similar to their practice with the 1993 engagement. Neither the Egyptian House of Representatives ${ }^{223}$

\footnotetext{
${ }^{217}$ Universal Declaration on Human Rights, 10 December 1948, Resolution 217 A(III), United Nations General Assembly.

${ }^{218}$ Declaration on Principles of International Law concerning Friendly Relations and Co-operation among States in accordance with the Charter of the United Nations. 24 October 1970, Resolution 2625 (XXV), United Nations General Assembly.

${ }^{219}$ Case Concerning Military and Paramilitary Activities in and Against Nicaragua (Nicaragua $v$ United States of America) Merits, Judgment ICJ Repts 1986, paras. 187-201

${ }^{220}$ Case Concerning Maritime Delimitation and Territorial Questions Between Qatar And Bahrain (Qatar v Bahrain) ICJ Repts 1994

${ }^{221}$ The Court concluded that 'the boundary between the Republic of Cameroon and the Federal Republic of Nigeria in the Lake Chad area is delimited by the Thornson-Marchand Declaration of 1929-1930, as incorporated in the Henderson-Fleuriau Exchange of Notes of 1931' (italics added) (Case Concerning the Land and Maritime Boundary Between Cameroon and Nigeria (Cameroon $v$ Nigeria: Equatorial Guinea intervening) ICJ Repts. 2002, paras. 325(1)[A], 54).

${ }^{222}$ Ibid, paras. 325(1)[A], 54

${ }^{223}$ Supra Constitution of The Arab Republic of Egypt 2014 note 6. Article (151): The President of the Republic shall represent the State in its foreign relations and conclude treaties and ratify them after the approval of the House of Representatives. Such treaties shall acquire the force of law following their publication in accordance with the provisions of the Constitution.
} 
nor the Sudanese National Legislature ${ }^{224}$ have approved the DoPs as required by both constitutions. Importantly, the Egyptian Constitution $2014^{225}$ maintains 'Egypt's [Nile] historic rights', which appears to be in conflict with the principles enshrined in the DoPs. Egypt and Sudan have not either formally denounced Nile colonial-era treaties ${ }^{226}$ or justified their compatibility with the DoPs. Certainly, colonial-era treaties ${ }^{227}$ appear to be in conflict with the DoPs, the equitable utilisation principle therein in particular. ${ }^{228}$ These are among the indications and circumstances that appear to suggest that the parties did not mean it to be a normative commitment.

In contrast, the second argument submits that the DoPs is a hard law agreement which must be honoured in 'good faith.' ${ }^{229}$ Such legal agreements do not necessarily need to be ratified by parliament to have international legal effect as ascertaining the intention to be bound by a treaty is determined and 'governed by international law. ${ }^{230}$ In the DoPs case, the intention of the parties can be inferred from the document itself. At the outset, the title of the instrument refers to 'agreement', which is different from the 1993 framework instrument. The Declaration not only sets out or reaffirms existing legal principles that are adopted in conventional and customary international law but also specific commitments some with immediate effect. This was one of the reasons why the ICJ ruled in support of

\footnotetext{
${ }^{224}$ Sudan's Constitution of 2005. Art 58 (1) (k).

225 The Constitutional provision states that: 'The state commits to protecting the Nile River, maintaining Egypt's historic rights thereto, rationalizing and maximizing its benefits, not wasting its water or polluting it...' (supra Egyptian Constitution note 6).

226 Aman, A., 'Egypt warily signs preliminary Nile agreement' Almonitor (31 March 2015) http://www.al-monitor.com/pulse/originals/2015/03/egypt-eastern-nile-water-agreement-ethiopiasudan.html\#.

227 (as discussed above ['Colonial Treaties and the Fairness of the GERD'] and discussed further later [Concluding Remarks]).

${ }^{228}$ Hammam, H., A Legal Analysis of the Declaration of Principles on the Grand Ethiopian Renaissance Dam, Public International Law Blog, https://law4371.wordpress.com/2015/05/08/alegal-analysis-of-the-declaration-of-principles-on-the-grand-ethiopian-renaissance-dam/.

${ }^{229}$ Supra Cameroon v Nigeria note 221, para. 39; supra VCLT note 139, Art. 26.

${ }^{230}$ International Law Commission First report on the law of treaties, Yearbook of the International Law Commission, Vol. II, 1962, p. 32.

http://legal.un.org/ilc/publications/yearbooks/english/ilc 1962 v2.pdf,
} 
Bahrain's argument that minutes of a meeting constituted a binding agreement. ${ }^{231}$ It is established in international law that 'a state may not invoke the provisions of its internal law as justifications for its failure to perform a treaty. ${ }^{232}$ From this, Ethiopia, Sudan and Egypt could not rely on their respective constitutions to not honour their commitments enshrined in the DoPs.

Furthermore, the reference to 'dispute settlement' and 'interpretation' of the agreement in accordance with 'the principle of good faith' (which borrowed the language of Art 26 of VCLT) is further evidence that the parties meant it to create legal rights and duties, although judicial and arbitral methods have not been referred to in the instrument. What methods of dispute settlement states adopt is a matter for states; which is why the selective approach taken by the DoPs may not show an intention not to be bound by the DoPs as a matter of law. Finally, the wording used to articulate the principles including 'shall' rather than 'would' or 'will', relating to the core principles enshrined in Articles 3 (equitable principle), 4 (not inflicting significant harm) and 7 (data exchange), amongst others is a sound textual evidence of intention to be bound by the terms and commitments. Unless this was caused by a bad drafting of the text, or a bad translation from the original languages, say from Arabic to English, ${ }^{233}$ these terms appear to connote a hard law instrument.

These assertions may well be challenged by the fact that the two downstream countries believe in the application of Nile colonial treaties which are not formally renounced (or upheld) in the DoPs. However, a state does not need to officially denounce prior legal commitments in order to endorse or reject a subsequent legal commitment as past treaties can be put aside or abrogated through the adoption of subsequent legal commitments on

\footnotetext{
${ }^{231}$ Supra Qatar v Bahrain note 220.

${ }^{232}$ Supra VCLT note 139, Art. 27; Legal Status of Eastern Greenland PCIJ Series A/B No 53 (5 April 1933), para. 5-18).

233 See e.g. the Arabic to English translation of the DoPs by Ahramonline http://english.ahram.org.eg/News/125941.aspx.
} 
the same subject matter. ${ }^{234}$ Such an abrogation of old Nile treaties based on the doctrine of lex prior can be justified and necessary for progressive development of the law. ${ }^{235}$

The third argument avoids, but also supplements, the two extreme views and submits that, whether hard or soft law, the DoPs is a declaratory and endorsement of modern principles and rules of existing customary international law, and those principles and rule, as reflected in the DoPs would be binding upon the parties. Even if the DoP itself is not legally binding upon the parties, the official endorsement of principles and rules of international law (by Egypt and Sudan in particular) can be seen as evidence of an emerging consensus in the Eastern-Nile basin to make an initial deal on the GERD and beyond based upon contemporary international law.

The question of implementing or disregarding the DoPs and associated undertakings as consensual commitments is a difficult one to deal with. One possible answer is that the commitments are not implemented and respected as the anticipated studies to be carried out by the French firm are delayed while the construction of the dam is ongoing. ${ }^{236}$ The other possible answer is that the parties to the DoPs are implementing and reaffirming their commitments. It can be argued that the delays caused by technical and administrative challenges that the three countries and the firms have been facing do not necessarily tell the tale of disregarding the commitments. For instance, the DoPs itself acknowledges that 'the Three Countries appreciate the efforts undertaken thus far by Ethiopia in implementing the IPoE recommendations pertinent to the GERD('s) safety. ${ }^{, 237}$ This

\footnotetext{
${ }^{234}$ Supra VCLT note 139, Art. 59(1)(b).

${ }^{235}$ Klabbers, J., 'The Vienna Convention and Conflicting Treaty Provisions', in, Enzo Cannizzaro, E., \& Arsanjani, M. H., The Law of Treaties Beyond the Vienna Convention pp.192-205 (Oxford University Press: Oxford, 2011), p.197.

236 'Ethiopia won't stop construction of the Renaissance Dam: minister' (Sudan Tribune, 13 February, 2016).

${ }^{237}$ Supra DoPs, note 12, Art VIII. For the Panel's partial report see 'International Panel of Experts (IPoE) on the Grand Ethiopian Renaissance dam Project (PERDP)' (2013) http://www.internationalrivers.org/files/attachedfiles/international panel of experts for ethiopian renaissance dam- final report 1.pdf.
} 
endorsement is important because the DoPs refers to the need for implementing the recommendations of the IPoE. Furthermore, the three countries adopted the December 2015 Khartoum minutes which reaffirmed their commitments to the DoPs led to: (a) the selection of two French firms to conduct the required studies and a British law firm to administer the contract between the parties; (b) adopting an Annex which contains the 'roadmap and plans for the studies'; and (c) to an agreement that a regular meeting at ministerial level continues to expedite the process. ${ }^{238}$ Most importantly, Article 5 of the Khartoum minutes

dealt with confidence-building and stated that the three countries agree to support and encourage efforts aimed at promoting confidence-building measures so as to enhance people-to-people relations of the three countries. Accordingly, Ethiopia invited parliamentarians, the media, and public diplomacy groups of both Egypt and Sudan to visit the GERD. ${ }^{239}$

In September 2016, these developments were followed by the signing of a contract between the three countries and BRLi Group and Artelia regarding the studies to be carried out regarding the impacts and hydrology of the GERD. ${ }^{240}$ According to an Egyptian newspaper, Ahramonline, the meeting that led to the signing of the contract

was conducted in a very friendly and warm environment and reflected the cooperation among the three countries and all in attendance expressed their support and appreciation for the efforts exerted by the three countries. ${ }^{241}$

However, whether the impact studies to be carried by the two French firms will arrive before or after the completion of the GERD remains to be seen. It is most likely that the two turbines (out of 16) of the GERD might commence generating electricity before the

\footnotetext{
${ }^{238}$ Supra Salman note 15, p 524.

${ }^{239}$ Ibid.

240 'Egypt, Ethiopia, Sudan sign final contracts on Nile dam studies' (Ahramonline, 20 September, 2016).

${ }^{241}$ Ibid.
} 
arrival of the studies/reports in the next couple of months. Even if they will not be used for, or help with, the actual construction of the dam, they may still be valuable for dealing with reservoir filling ${ }^{242}$ and operating of the dam.

From an Egyptian (and possibly Sudanese) perspective it might be argued that the continuation of GERD's construction, without considering the outcomes of the forthcoming studies disregards Ethiopia's commitment to the DoPs. From the Ethiopian perspective, however, this assumption has several defects. First, the outcome of the studies may or may not have any implication for the way in which Salini is constructing the GERD; secondly, demanding a halt of construction because of technical and administrative hurdles will be very costly to Ethiopia; thirdly, the delays on commencing the studies cannot be attributed to Ethiopia alone-all the parties including the private firms have contributed to the delays ${ }^{243}$ in one way or the other; fourthly, there is no evidence that the DoPs was agreed in the spirit that the construction of the dam was conditional upon the studies contemplated to be carried; as the ICJ in the Pulp Mills case specifically pronounced the position of the law on this stating that suspension (of the Pulp Mills project) is only possible "in conformity with the provisions of the treaty" or "by consent of all the parties,"244 and finally, as the Dams Commission hints, it may not be equitable and reasonable to halt the GERD project simply because there is a delay in forthcoming studies by foreign firms which are not of binding character. Some of these issues will be revisited when the DoPs' connotations to the fairness principle are considered later.

To recap, the parties have not only come up with solid agreement of principles but they are also implementing, or trying to implement, the commitments adopted in the DoPs, although the process does not appear to be a smooth ride. Regardless of the validity of the

\footnotetext{
${ }^{242}$ Supra Salman note 15, p. 524

${ }^{243}$ See e.g. 'Egypt announces postponement of GERD impact studies contracts signing' (Ahramonline, 4 September, 2016).

${ }^{244}$ Supra Case Concerning Pulp Mills on the River Uruguay note 46, para 141.
} 
various scenarios drawn on the legal status of the instrument, the DoPs evidences the beginning, but not the end, of a new era — whether that era is that of fairness or status quo ante depends on the appreciation and interpretation of the commitments made in the instrument.

\section{GERD's Fairness in the Eyes of post-1990 Commitments:}

The objective of this section is to tackle the fairness of damming the Blue Nile and its implications for cooperation from the perspective of non-colonial-era commitments. While the DoPs offers solid perspectives on distributive justice aspect of fairness, the 1993 instrument poses more procedural questions as the next section exhibits.

\section{GERD's Procedural Fairness}

The 1993 instrument was among the grounds relied upon either to challenge or justify the procedural fairness of the GERD. Shetewy, for example, impliedly argues against the construction of the GERD on the ground that Ethiopia, as well as Egypt, has, in the 1993 instrument, pledged to conduct consultations and establish joint mechanisms and studies for using Nile waters. ${ }^{245}$ According to this position, thus, Ethiopia has 'failed' to comply with these pledges and therefore infringed procedural fairness.

From an Egyptian perspective, furthermore, Ethiopia did not comply with the procedural duty of prior notification and consultation concerning technical data and potential impact of the GERD before commencing construction. This is particularly true if it was thought

${ }^{245}$ Supra Shetewy note 124, p. 35. 
that the project may have a significant adverse effect on the downstream states. ${ }^{246}$ As a matter of law, Ethiopia only have to notify if its planed project 'may have a significant adverse effect upon other watercourse States', as expressly enshrined in Art 12 of the UNWCC. Although the duty to notify does not equate to the right to veto a planned project, it is said that it has attained either a general principle or a customary law status in the field of watercourses law. ${ }^{247}$

Given that this is a procedural duty, however, it is normally and primarily applied within a treaty framework. ${ }^{248}$ Most importantly, in situations where two or more basin states are not parties to relevant international, basin-level or bilateral agreements that oblige to notify on planned projects, and non-notification is the norm rather than the exception in relations among co-riparians, ${ }^{249}$ the application of the principles of reciprocity and equity to such situations ought not be ignored. ${ }^{250}$ As the P.C.I.J. put it:

It would seem to be an important principle of equity that where two parties have assumed an identical or a reciprocal obligation, one party which is engaged in a continuing non-performance of that obligation should not be permitted to take advantage of a similar non-performance of that obligation by the other party. ${ }^{251}$

In this respect, what Egypt had demanded was what it has never given to Ethiopia and other upstream countries. The planned project to build the Aswan High Dam was not shared with Ethiopia. Most significantly, Egypt never consulted with or shared the benefits

\footnotetext{
${ }^{246}$ Supra UNWCC note 65, Arts. 11-12; supra Shetewy note 124, pp. 30-31.

247 Wouters, P., International Water Law: Selected Writings of Professor Charles B. Bourne (Martinus Nijhoff: Leiden, 1997), p. 182. The ICJ in the Pulp Mills case (supra note 46) states that 'the obligation to inform CARU (a body established by a treaty) allows for the initiation of cooperation between the Parties which is necessary in order to fulfil the obligation of prevention' (para 102).

${ }^{248}$ Supra Pulp Mills case note 46, paras 112-122, see para 122 in particular. In this case the 1975 Statute (a treaty) signed by both countries enshrined inter alia 'the obligation of prior notification.' The Court adopted the same approach in Dispute Regarding Navigational and Related Rights [San Juan River Cases] (Costa Rica V. Nicaragua) ICJ Judgment of 13 July 2009, paras 91-97.

${ }^{249}$ Supra Salman note 92, p.22.

${ }^{250}$ Supra Division of Water case note 59, para. 323.

${ }^{251}$ Ibid.
} 
of the South Valley Toshka scheme, (as well as Al Salam Canal, designed to divert the Nile to Sinai) with upstream countries. ${ }^{252}$ The Aswan Dam issue may only be of historical significance here. The South Valley/Toshka scheme, in contrast, began in 1997, after the signing of the 1993 instrument, and meant to expand Egypt's irrigated land by 'up to 3200 sq.km' and has the capacity of accommodating around six million Egyptians. ${ }^{253}$ This is a new and ongoing development which reinforces the prior apportionment claim by Egypt over Nile waters, which requires an additional 5-10 billion cubic meters of Nile waters. ${ }^{254}$ Without going into the polemics of the impact of this project on the Nile river system, the facts that occurred before and after the 1993 instrument speak for themselves concerning the unjustifiability of Egypt's attempt to object to the GERD on the basis of not being notified and consulted about it during planning.

Yet the duty to notify and consult is seen as customary law, ${ }^{255}$ hence, of an erga omnes character owed to all Nile basin countries-its violation by Egypt with respect to the Aswan Dam or its most recent project does not justify Ethiopia's 'failure' to notify and consult with Egypt. The problem of such a noble but 'rigid' application of a procedural rule without sufficient account of practices and behaviours of riparian states in a particular river basin context would run contrary to what the P.C.I.J. termed the principles of reciprocity and equity, that require equal treatment and expectation of all basin states in applying legal rules and principles. ${ }^{256}$ Furthermore, if a riparian state invokes a violation of a procedural rule of international law by another co-riparian state, whilst itself is engaged

\footnotetext{
${ }^{252}$ Yigzaw, Z.A., Open Letter to Egypt: A Response to The Spokesman of Egypt's Ministry of Foreign Affairs Regarding the GERDP from An Ethiopian Perspective, Sodere, http://sodere.com/profiles/blogs/open-letter-to-egypt-a-response-to-the-spokesman-of-egypt-s.

${ }^{253}$ Wahish, N., 'Toshka turns millennial green' (Al-Ahram Weekly On-line, 27 Aug. - 2 Sep. 1998, Issue No.392) http://weekly.ahram.org.eg/archive/1998/392/ec1.htm

${ }^{254}$ Supra Woldetsadik note 128, pp.44-45; Cascão, A. E., 'Changing Power Relations in the Nile River Basin: Unilateralism vs. cooperation?' Water Alternatives 2(2) pp. 245- 268 (2009), p. 249.

${ }^{255}$ Rieu-Clarke, A., 'Notification and Consultation on Planned Measures Concerning International Watercourses: Learning from the Pulp Mills (supra note 27) and Kishenganga Cases' Yearbook of International Environmental Law Vol. 24(1) pp. 102-130 (2014), pp. 102-130.

${ }^{256}$ Supra Division of Water case note 59; supra CFA note 94, Art. 10.
} 
in violating the same rule, that conduct may amount to abuse of rights and processes ${ }^{257}$ and thus unjust. This is further strengthened by the fact that Ethiopia strongly believes in the absence of a significant risk of harm to downstream countries as a result of its dam project. It is doubtful that the doctrine of abuse of rights or processes exists in international law, ${ }^{258}$ and thus the rule of prior notification or consultation, as enshrined in article 11 of the UNWCC ought to be adhered to strictly, disregarding the peculiar complexities of the practices and contentions over shared Nile water. If this line of argument holds true both Egypt and Ethiopia would be responsible for not honouring their respective commitments not to engage in Nile planned projects without a joint study and prior notification and consultation, as can be broadly inferred from the 1993 instrument; notwithstanding the controversy surrounding the binding nature of the instrument. Furthermore, as the ICJ in the Pulp Mills case affirmed every State's duty 'not to allow knowingly its territory to be used for acts contrary to the rights of other States. ${ }^{, 259}$ It follows from this that 'a State is ...obliged to use all the means at its disposal in order to avoid activities which take place in its territory, or in any area under its jurisdiction, causing significant damage to the environment of another State.' 260 This is termed by the Court as the duty of prevention the implementation of which is reliant on cooperation between concerned parties. The duty to inform/notify 'allows for the initiation of (such) co-operation. ${ }^{\text {'261 }}$ This due diligence expectation may therefore apply to both Ethiopia and Egypt.

Egypt may also be found responsible for breaking the 1993 instrument as the statements made during the Morsi era and for early reports that indicate the plans and 'determination' of Egypt to use military force, or threat of force, subversion and the likes to halt the

\footnotetext{
${ }^{257}$ Lauterpacht, H., The Function of Law in the International Community (Oxford University Press: Oxford, 2011), pp. 306-307.

${ }^{258}$ Supra Wouters note 247, p. 76.

${ }^{259}$ Supra Pulp Mills case note 46, para 101.

${ }^{260}$ Ibid.

${ }^{261}$ Ibid, para 102.
} 
GERD's construction; ${ }^{262}$ these may have contravened 'the principles of good neighbourliness, peaceful settlement of disputes, non-interference in the internal affairs of states. $^{263}$ Such Egyptian conduct also defeats the core of UN Charter and AU commitments of the Country as deploying, or threatening to deploy, military force to promote economic or other interests of a state is firmly prohibited in contemporary international law. ${ }^{264}$ Yet it was/is not clear whether the threatening statements made by Egyptian politicians in particular where mere political rhetoric or steps taken as part of a concrete and planned state action. ${ }^{265}$ In recent months, however, 'Ethiopia has accused Egypt and Eritrea of destabilizing its stability by supporting outlawed rebels and stoking an unprecedented wave of protests that has led the government to declare a six-month state of emergency, ${ }^{, 266}$ an allegation swiftly denied by Egypt. ${ }^{267}$

Such accusations and counter-accusations on past and recent events are less likely to help promote genuine cooperation among the parties, which is the prime objective of a fair process. In part, therefore, this discussion may be academic and obsolete. Furthermore, the 1993 instrument offers far beyond the two main issues discussed thus far, the general ban on the use of Nile waters and prior notification as procedural matters. For instance, both sides agreed to "create appropriate mechanism[s] for periodic consultations" ${ }^{268}$ and most importantly, they committed themselves to work 'towards a framework for effective cooperation among countries of the Nile Bain. ${ }^{269}$ These are positive commitments which

\footnotetext{
${ }^{262}$ Whittington, D., Waterbury, J., \& Jeuland, M., 'The Grand Renaissance Dam and Prospects for Cooperation on the Eastern Nile' Water Policy Vol. 16(4) pp. 595-608 (2014), doi: 10.2166/wp.2014.011, p. 598; supra Kelley \& Johnson note 11.

${ }^{263}$ Supra 1993 Framework Instrument note 173, Art. 1.

${ }^{264}$ Gray, C., 'The Use of Force and the International Legal Order', in, Evans, M. D., International Law 3rd ed. pp. 615-647 (Oxford University Press: Oxford, 2010), pp. 618-619.

${ }^{265}$ Supra Yihdego note 170.

${ }^{266}$ Ali, N., 'Ethiopia Accuses Egypt of Destabilizing the Country by Supporting Rebels' (Middle East Observer, 11 October, 2016).

267 'Egypt's Sisi denies supporting opposition in Ethiopia' (Reuters 13 October, 2016).

${ }^{268}$ Supra 1993 Framework Instrument note 173, Art. 7.

${ }^{269}$ Ibid, Art. 8.
} 
might have contributed to the endeavour made to establish the NBI, and ultimately the CFA.

Undoubtedly, the DoPs has opened a new chapter of cooperation, and provides a comprehensive insight into the procedural fairness of the GERD. Before dealing with the fairness of the adoption and implementation processes of the DoPs, a background discussion on the design of the project is desirable to see to what extent GERD's initial processes were participatory of relevant stakeholders in accordance with internationally acceptable standards. The Dam's Commission rightly states that:

Large dams arise from a series of decisions taken from the beginning of the planning process through to the final approval of a project and financial closure. At each stage different actors are involved, including government agencies, public or private utilities, interested parties from the region, financing agencies, consulting and construction companies and equipment suppliers. Affected people and NGOs are increasingly involved as well. ${ }^{270}$

The GERD appear to have secured the participation of most, if not all, these actors and their vital roles in the process of designing and planning the project. The following three points demonstrate this. First, building upon previous studies, the government conducted a serious of studies including dam design, environmental and socio-economic impact assessment, initial transboundary environmental impact assessment and flood analysis. ${ }^{271}$. The IPoE, it its 2013 report, confirmed, for example, that the content and structure of the environmental impact assessment conducted to identify the impacts of the GERD on Ethiopia, Sudan and Egypt met the standards of international financial institutions ${ }^{272}$.

\footnotetext{
${ }^{270}$ Dams and Development a New Framework for Decision-making: The Report of the World Commission on Dams (Earthscan, London and Sterling, 2000) p. 167.

${ }^{271}$ Supra IPoE Report note 237, pp14-39.

${ }^{272}$ Ibid. See in particular p.28.
} 
Similarly, the hydrological study on flood analysis was generally acceptable. ${ }^{273}$ The Panel has also made recommendations as further elaborated in relation to implementation of the project and the DoPs.

Secondly, the Geotechnical Mission Report ${ }^{274}$ prepared by the contractor, Salini, was also said to be of an internationally acceptable quality by the IPoE. Salini is not the only European company that is involved in the GERD's design and implementation. Alstom, a French company, has signed 250 million Euro worth contract in 2013 with the state-owned Metals \& Engineering Corporation (METEC), to supply all GERD turbines, other electrical equipment and supervise their installation. ${ }^{275}$ The Chinese have been part of the design and execution of building transmission lines from the GERD to the national grid 276 too.

Thirdly, the GERD was designed to be financed by the Ethiopian government and the public which makes it a unique self-funded mega project, free of foreign loan or aid. The Ethiopian public both at home and abroad was made aware of the commencement of the project including on the modality of financing the project. As will be seen in a while, despite some legitimate questions and doubts by some quarters, Ethiopians and foreign citizens of Ethiopian origin have rallied around financing and supporting the GERD project. $^{277}$ This includes those who are, or will be, displaced ${ }^{278}$ by the project. Ethiopian

\footnotetext{
${ }^{273}$ Ibid, p,34.

${ }^{274}$ Ibid, p. 29.

275 'Alstom to supply hydroelectric equipment for the Grand Renaissance dam in Ethiopia' 07/01/2013http://www.alstom.com/press-centre/2013/1/alstom-to-supply-hydroelectric-equipmentfor-the-grand-renaissance-dam-in-ethiopia/.

276 Tadele, Y. 'EEPCo, Chinese Company Ink Billion Dollar Transmission Line Deal', Fortune, 28 April 2013 [VOL 13 ,NO 678].

${ }^{277} \mathrm{http}: / / \mathrm{www} \cdot h i d a s s e . g o v . e t /$.

278 Veilleux, J., 'The Human Security Dimensions of Dam Development: The Grand Ethiopian Renaissance Dam' Global Dialogue Volume 15, Number 2, Summer/Autumn 2013-Water: Cooperation or Conflict? P. 10.
} 
local and international civil and professional societies firmly support(ed) the initiation of the GERD ${ }^{279}$ while the US-based, International Rivers opposed it from the outset.

However, the two downstream countries, Egypt and Sudan did not participate in the design of the GERD. The procedural fairness of the initiation of the GERD might therefore be doubted. The unilateral nature of the dam project which was initiated in the absence of relevant treaty regime between the three countries might justify the non-participation of the two key stakeholders at the beginning. Although the size of the GERD is much bigger than previous plans, it might be argued that Egypt and Sudan participated in previous planning and design of a dam which was intended to be built on the Blue Nile within the NBI framework. ${ }^{280}$ Furthermore, even if the procedural fairness of the beginning of the GERD is characterised by this likely 'weakness', the three aforementioned points broadly affirm that the initial process was not only participatory but also founded on scientific studies and processes involving internationally (and nationally) recognised actors. Most importantly, fairness is a process, and might not begin as a perfect one. And also the two downstream countries were later 'invited in good faith ... to review the design documents of the GERD, ${ }^{281}$ with the purpose of building trust and confidence among the three eastern Nile countries.

Furthermore, the adoption of the DoPs by the three countries seems to have rectified what was missing at the design level by making links between issues of design and other studies and implementation of the Declaration, as shall be addressed in a moment. The question is, however, was the adoption of the DoPs fair? The series of meetings held among the three countries were attended by representatives of the three countries at technical, ministerial

\footnotetext{
279 See e.g. Ethiopian International Professional Support for Abay (EIPSA) http://www.eipsa1.com/cms/.

${ }^{280}$ Cascão, A., \& Alan Nicol, A., ' GERD: new norms of cooperation in the Nile Basin?, Water International, (2016) Vol41, Issue 4, pp.559-560.

${ }^{281}$ Supra IPoE Report note 237, p. 1.
} 
and head of state/government levels, ${ }^{282}$ and therefore mirror equality, serious exchange of ideas and a sprite of cooperation. The negotiations have provided the parties with opportunities to exchange their hopes and fears and also make compromises, as can be shown from the DoPs itself-for example, Ethiopia agreed to use the GERD for energy generation purposes and give electric sale priority to Sudan and Egypt, while the two downstream countries have made unprecedented move to endorse contemporary principles of international watercourses law. This is further evidence that the adoption of the DoPs arguably is a result of a fair process. What is clear at this point is that the legality of the construction of the GERD has become uncontentious. Indeed, the dam has been seen as an opportunity to foster development and integration. ${ }^{283}$ This does not close the question of fair and legitimate adoption and participation, however.

It is contended that Ethiopia has forced Egypt (and not Sudan) to agree on the construction and operation of the dam as a fait accompli. ${ }^{284}$ It appears from the terms of DoPs itself, ${ }^{285}$ earlier statements made by Egyptian officials and from the major shift of position shown that Egypt might have made an informed decision to support, or even to participate in jointly building, the GERD ${ }^{286}$ as beneficial to its water, energy and other geo-political interests; this is of course conditional, amongst others, upon agreed dam filling and

\footnotetext{
${ }^{282}$ Supra Salman note 15.

${ }^{283}$ Supra DoPs note 12, Art. ii.

284 'Egypt Forced to Negotiate on Nile Dam' (Stratfor, 20 March, 2015)

https://www.stratfor.com/sample/analysis/egypt-forced-negotiate-nile-dam;

Verhoeven, H., Africa's Next Hegemon: Behind Ethiopia's Power Plays, Foreign Affairs, https://www.foreignaffairs.com/articles/ethiopia/2015-04-12/africas-next-hegemon;

Farid, S., 'Will Egypt still get its fair share of Nile water?' (Al Arabiya News, 31 March, 2015) http://english.alarabiya.net/en/perspective/analysis/2015/03/31/Will-Egypt-still-get-its-fair-shareof-Nile-water-.html.

${ }^{285}$ Supra DoPs note 12 , Art II.

${ }^{286}$ Aman, A., 'In switch, Egypt may join Ethiopia in Nile Dam project', Al-monitor, 21 October 2013:

http://www.al-monitor.com/pulse/originals/2013/10/egypt-ethiopia-damreconciliation.html\#ixzz4UK9hCjUq.
} 
operation policy. ${ }^{287}$ To Sudan, in contrast, 'backing the dam project is not a political stance, but rather a belief in its benefits for all Nile Basin states ${ }^{288}$. This belief of president Omar Al-Bashir is shared by scholars with specific reference to the benefits of the dam to Sudan. ${ }^{289}$

Ethiopia, for its part, as a good example of compliance with its due diligence duty to take 'all appropriate measures' to prevent harm, ${ }^{290}$ went to the extent of inviting Egypt and Sudan to establish a Tripartite Joint Commission and an IPoE to follow up the construction of the GERD and associated issues arising from its design, construction and operation, with the purpose of ensuring downstream participation in pre-and-post project completion policy and operational matters. This was also commended by the IPoE. ${ }^{291}$ However, despite undertaking internal and (initial) transboundary environmental (and social) impact assessments that were said to have met international funding agencies' standards, the IPoE recommended that further studies are needed to elaborate on some of the studies conducted with emphasis on downstream impacts. ${ }^{292}$ Ethiopia accepted to strengthen its studies. Despite varied interpretations of the findings and recommendations of the IPoE report, the parties recognise Ethiopia's efforts to 'implementing the IPoE recommendations'. ${ }^{293}$ As considered previously the contract signed between the three countries and the two French firms is intended to follow up the suggestions made by the IPoE.

The parties have now agreed 'to cooperate on the first filling and operation' of the GERD, ${ }^{294}$ the details of which will be informed by the IPoE report, joint studies and

\footnotetext{
${ }^{287}$ Ibid. There was also a demand for a reduced size of reservoir which was rejected by Ethiopia.

${ }^{288}$ Eleiba, A., 'Sudanese president backs Ethiopian dam ahead of Nile talks' (Ahramonline, 5 December, 2013).

${ }^{289}$ Tawfik, R., The Grand Ethiopian Renaissance Dam: a benefit-sharing project in the Eastern Nile? Water International (2016) pp. 574-592.

${ }^{290}$ Supra UNWCC note 65, Art. 7(1).

${ }^{291}$ Supra IPoE note 237.

${ }^{292}$ Ibid, p. 39-40; see also supra Pulp Mills case note 46, paras. 203-219.

${ }^{293}$ Supra DoPs note 12, Art. VIII.

${ }^{294}$ Ibid, Art. V.
} 
decision of the three countries $;{ }^{295}$ joint technical national committees and a Committee of Water (and Foreign) Ministers are empowered to deal with this crucial task. The reference to the Heads of State (or Government) of the three countries as ultimate arbitrators in case a dispute arises is an important mechanism for fully and flexibly implementing the Declaration. The Dam's Commission Guidelines on dam related disputes refer, however, to 'good faith negotiations or independent dispute resolution procedures.' ${ }^{296}$ Political methods of dispute settlement are certainly more flexible, swift and less costly, when undertaken in good faith and spirit of cooperation, compared to legal or other independent methods of dispute settlement.

In brief, the DoPs secured consensus of the three eastern Nile basin countries on the continuing construction of the GERD and the way in which it will be filled, operated, and the benefits shared - an exemplary practice promoting procedural fairness in the use of shared water resources such as Nile waters. The project design and implementation have also involved various actors---government agencies, the three countries, contractors and suppliers, foreign consultancy firms and communities, although not without shortcomings. Translating such key consensual commitments and processes into distributive justice is a necessary but difficult exercise, as the next section will show.

\footnotetext{
${ }^{295}$ Supra Zhang et al note 20; see also Wheeler, K.G., Basheer, M., Mekonnen, Z.T., Eltoum, S.O., Mersha, A., Abdo, G.M., Zagona, E.A., Hall, J.W., \& Dadson, S.J., 'Cooperative filling approaches for the Grand Ethiopian Renaissance Dam' Water International (2016) Vol 41, Issue 4, pages: 611-634.

${ }^{296}$ Supra World Commission of Dams Report note 270, p. 267.
} 


\section{GERD's Distributive Fairness}

\section{Some Key General Issues}

Contrary to questions of GERD's procedural fairness, which appears to have been put to rest in March 2015, evaluating the distributive justice impacts of GERD based upon the two post-1990 instruments is much more intricate. Undoubtedly, the 1993 engagement conveys, in incomplete terms, a message of distributive justice on the sharing of Nile resources, which may be used to support or question the fairness of the GERD. The instrument provides the commitment to cooperate on advancing 'economic and political interests' of both sides. ${ }^{297}$ This must be read in conjunction with the term 'mutual interest' which is repeatedly referred to as a foundation for their cooperation on Nile and other matters. Furthermore, conserving and protecting Nile waters by enhancing 'the volume of flow and reduce the loss of Nile waters ${ }^{298}$ constitutes one of the core commitments. The engagement also reaffirms the prevention of causing 'appreciable harm'. ${ }^{299}$ By endorsing the interests of both parties, these basic commitments broadly advance some of the requirements of distributive justice, which also take into account preserving Nile waters as duly considered hitherto. However, the instrument offers almost nothing with respect to substantive water use rights of the parties, and thus is not a complete instrument for fostering distributive justice.

Egypt relied on the appreciable harm clause inter alia of the 1993 commitment to argue that the GERD will be detrimental to its agriculture, fisheries, and hydropower and harm to the natural environment. ${ }^{300}$ If substantiated, this claim would make the GERD at odds with

\footnotetext{
${ }^{297}$ Supra 1993 Framework for Cooperation note 173, Art. 3.

${ }^{298}$ Ibid, Art 6.

${ }^{299}$ Ibid, Art 5.

${ }^{300}$ Supra Egypt's Perspective note 5.
} 
distributive justice. Ethiopia strongly contests this and sees the dam as beneficial in regulating flooding, slit, increasing Blue Nile flows and reducing evaporation loses from the Aswan dam and other storage dams in Sudan thus promoting some of the terms of the 1993 instrument. All these assertions including the clean energy generation and sharing promote mutual interest and a 'win-win' situation among the parties, and thus do justice rather than harm. ${ }^{301}$ Different from the 1993 instrument, however, the DoPs has adopted ten general and specific principles of international (watercourses) law as considered earlier that laid down fundamentals of a fair deal for all concerned, which is entirely different from old Nile treaties and practices. The DoPs, building upon the core principles, attempts to balance conflicting interests. Ethiopia's right to use the river for hydropower generation is firmly endorsed. In fact, the DoPs recognises the dam as a drive for regional integration and sustainable development. However, it barred the dam from being used for irrigation purposes, which provides a 'symbolic' guarantee to Egypt and Sudan. In addition to such a bar, Ethiopia has agreed to share the benefits of the GERD by giving priority of exporting electricity to Sudan and Egypt. By this account, the GERD's fruits will be shared by the three and other Nile riparian countries and thus appear to be in line with the notion of 'broadly conceived equity.' ${ }^{302}$

However, Mohamed Nasreddin reportedly criticised the DoPs inter alia for not clearly referring to Egypt's historic rights and past agreements including the 1902 Nile treaty. ${ }^{303}$ Conversely, Minga Negash et $\mathrm{al}^{304}$ argue that 'the [DoPs] clauses are designed to re-assert the 1929 and 1959 water sharing agreements' including the 1993 instrument. These two extreme positions do not do justice to the DoPs as the instrument is founded on equitable

\footnotetext{
${ }^{301}$ Supra Whittington note 262, pp. 596, 600; Supra MIT Report note 10.

${ }^{302}$ Supra Franck note 28, p. 56.

303 'Al-Sisi criticised for waiving Egypt's right over Nile water' Middle Eastern Monitor (23 March 2015) https://www.middleeastmonitor.com/news/africa/17657.

304 Negash, M., Hassan, S., Muchie, M., \& Girma, A., 'Perspectives on the Declaration of Principles regarding the Grand Ethiopian Renaissance Dam' The Thinker Vol. 65 pp. 56-61 (2015)
} 
utilisation and participation, guaranteeing the two countries water use rights 'consistent with international law. ${ }^{305}$ This is not to denounce reasoned criticisms of the Declaration. Negash et al, for instance, argue that Article ii of the Declaration 'can be interpreted to exclude... the use of the waters for fishing, recreation, education and small scale industrial and irrigation projects around the dam' and thus are 'devoid of shared benefits and responsibilities. ${ }^{306}$ It is doubtful that the DoPs was meant to ban non-harmful use of dam water such as fisheries, tourism and planting trees in the dam area some of which are clearly envisaged since the project's inception. ${ }^{307}$ However, the DoPs rightly, but controversially, gave an apparent guarantee to Egypt and Sudan that the (key) purpose of the dam is not for irrigation uses. The DoPs could, however, be said to be unfair for Ethiopia as the full costs of the project are to be met from state and citizens' coffers, ${ }^{308}$ while the benefits will be shared with others. Egypt has managed to block all avenues of external funds for the GERD, ${ }^{309}$ despite some early reports suggesting that it offered to help financially. ${ }^{310}$ Egypt's policy on external finances for upstream projects does not appear to have been discontinued post-DoPs. In this context one may question whether the deal made to export electricity to Egypt as a matter of priority is a fair deal for Ethiopia, although this will depend on the price to be fixed. As the filling, operation and flow of the dam might be heavily or lightly regulated in the interest of Egypt and Sudan, some level of

\footnotetext{
305 Afifi, H., 'Egyptian experts divided over Renaissance Dam declaration of principles' Ahramonline (24 March 2015) http://english.ahram.org.eg/NewsContent/1/64/126005/Egypt/Politics-/Egyptian-experts-dividedover-Renaissance-Dam-decl.aspx.

${ }^{306}$ Supra Negash et al note 304.

307 Grand Ethiopian Renaissance Dam, EEPCo (Ethiopian Electric Power Corporation), http://www.eepco.gov.et/abouttheproject.php?pid=1\&pcatid=2.

${ }^{308}$ Supra MIT Report note 10.

309 'A dam nuisance: Egypt and Ethiopia quarrel over water' (The Economist, 20 April, 2011) http://www.economist.com/node/18587195.

310 Maasho, A., 'INSIGHT-Paying for giant Nile dam itself, Ethiopia thwarts Egypt but takes risks' (Reuters, 23 April 2014)

http://www.reuters.com/article/ethiopia-energyidUSL6N0N91QM20140423\#0yFaPZTMs1UPhfBG.97.
} 
cost sharing would be imperative as part of the fair deal system. With respect to the Owen Falls dam of Uganda, Egypt was subjected to a 4.5 million Egyptian pounds expenditure to cover the costs of the dam in return inter alia for direct control of the flow of the dam. ${ }^{311}$

\section{Dam Filling and Operation}

To introduce a fair deal relating to the filling and operation of GERD requires an agreement on relevant principles and specific rules and guidelines. Article V of the DoPs, titled, 'Principle to cooperate on the First Filling and Operation of the Dam', should be the basis to consider what a fair filling and operation should look like.

\section{Dam operation}

Paragraph ' $b$ ' of Article V stipulates that the three countries 'agree on guidelines and rules for the annual operation of GERD, which the owner of the dam may adjust from time to time.' Under paragraph ' $\mathrm{c}$ ' of the same principle it is further provided that: 'to sustain cooperation and coordination on the annual operation of GERD with downstream reservoirs, the three countries, through the line ministries responsible for water, shall set up an appropriate coordination mechanism among them.' In addition to the agreement on setting up suitable institutional mechanisms, this expressly recognises (a) the need for coordination between the operation of the GERD and downstream dams, and (b) the interests of both upstream and downstream parties, with the owner exercising some discretion to make adjustments on agreed operation plans. The studies to be conducted based upon the recommendations of the IPoE will, and should, feed into rules and modalities of dam operation and coordination to be agreed upon by the three countries.

${ }^{311}$ Supra Woldetsadik note 128, p. 41. 
Making this arrangement in line with the spirit of distributive justice would not be an easy matter. Egypt ${ }^{312}$ and Sudan might claim that the operation of the dam with respect to water flow regulation must not affect their current or historic use as set out in colonial-era Nile treaties, although this conflicts with the underlying principles adopted in the DoPs of 2015. In contrast, Ethiopia will most likely rely on its customary international law entitlement to equitable use as also accepted by the three parties. The 2014 MIT Report on the very same question stresses that operations of the GERD and downstream reservoirs ought to be coordinated 'to ensure that economic and financial benefits are realized, and that the waters are equitably shared among all users. ${ }^{313}$

However, Ethiopia has to operate and use the dam in compliance with the duty to prevent significant harm on Sudan and Egypt. Customary international law, the DoPs and Ethiopia itself recognise this obligation. The MIT report further recommends that 'to achieve Ethiopia's "no harm" goal, it is important that the GERD, AHD, and Sudan's reservoirs be operated in coordination by Egypt, Ethiopia, and Sudan. ${ }^{314}$ Ethiopia reiterated time and again that neither does it have the intention to harm Egypt and Sudan nor the studies it has conducted indicate such impacts. Given that GERD's purpose and suitability is for hydropower generation and once the reservoir is filled with water, 'Ethiopia will want to maintain large releases of water through the turbines in order to maximize its hydropower revenues. ${ }^{315}$ Apart from safety and similar issues, as considered earlier, therefore, the potential of significant harm from GERD as a result of reduced water flow is remote in normal (excluding drought-like) dam operation conditions. The MIT report supports this assertion that 'most of the time there will be relatively little conflict between Ethiopia's desire to maximize the value of the GERD's hydropower production and the water

\footnotetext{
312 Aman, A., 'Egypt warily signs preliminary Nile agreement' (Al-Monitor, March 31, 2015).

${ }^{313}$ Supra MIT Report note 10, p.3.

${ }^{314}$ Ibid, p 3.

${ }^{315}$ Ibid, p. 6.
} 
requirements of downstream users. ${ }^{316}$ For this reason, the question of harm arising from dam operation and water flow regulation, as an aspect of distributive justice, appears to be academic.

\section{Dam filling}

In contrast, GERD's reservoir filling poses immediate and practical hopes and concerns to the dam owner and the two downstream countries respectively. The MIT report meticulously summaries this tension as follows:

Both Sudan and Egypt should be especially interested in GERD releases during filling and periods of drought, because at these times the interests of the downstream riparians differ from those of Ethiopia. Egypt and Sudan need releases from the GERD to meet minimum water requirements, but Ethiopia may prefer to increase the quantity of water stored in the GERD reservoir. ${ }^{317}$

Questions of dam filling and coordination of different reservoirs during filling are largely technical matters. The legal basis that inform a fair filling legal and policy option for the GERD are of interest here. Article V of the DoPs provides that:

The Three Countries, in the spirit of cooperation, will utilize the final outcomes of the joint studies, to be conducted as per the recommendations of the IPoE Report and agreed upon by the TNC, to ... agree on guidelines and rules on the first filling of GERD which shall cover all different scenarios, in parallel with the construction of GERD. ${ }^{318}$

\footnotetext{
${ }^{316}$ Ibid, p. 4.

${ }^{317}$ Ibid, p. 5.

${ }^{318}$ Supra DoPs note 12, Art V, Para 2 (a).
} 
Until now no agreement has been reached on dam filling guidelines and rules for the GERD by the three countries. ${ }^{319}$ However, the MIT 2014 Report and subsequently published scholarship have dealt with some general and detailed filling scenarios and options for the GERD. The MIT Report, recognising Ethiopia's natural desire and incentive to fill out the dam quickly and downstream impacts of such speedy filling, recommended an agreement on dam filling to be flexible and adaptable

to the actual sequence of Nile flows that occurs while the GERD reservoir is filling. It must be able to meet the agreed objectives given the many possible conditions of the Eastern Nile water resource each year: AHD reservoir storage level, the GERD storage level and Blue Nile flow. For example, if during filling of the GERD reservoir the AHD is full, Egypt could draw down the AHD reservoir to meet its water requirements as Blue Nile flow is stored in the GERD reservoir, effectively shifting storage upstream and reducing evaporation losses from the AHD reservoir ... However, if the AHD reservoir storage is low, then less Blue Nile flow could be stored in the GERD reservoir and agreed downstream releases could be made for Egypt and Sudan.... Any filling agreement must have provision for meeting the minimum water requirement for Egypt and Sudan. ${ }^{320}$

In contrast, Zhang, Erkyihun and Block ${ }^{321}$ proposes a fixed annual or monthly release of water combined with a pre-defined number of years for filling. Unlike the MIT report, this approach provides with specific scenarios and options for GERD filling. Without trying to predict the effects of climate change on the streamflow of the Blue Nile, Zhang et al looked at three fixed filling scenarios and options, 4, 6 and 8 and 10+ years of filling the dam. The 4 and 10+ years filling options are seen as two extreme options that might be

${ }^{319}$ Yihdego, Z., Rieu-Clarke, A., \& Cascão, A., 'How has the Grand Ethiopian Renaissance Dam changed the legal, political, economic and scientific dynamics in the Nile Basin?' Water International (2106) Vol. 41, Issue 4, p.507.

${ }^{320}$ Supra MIT Report note 10, p. 4.

${ }^{321}$ Supra Zhang et al note 20, pp. 593-610. 
favoured by Ethiopia and downstream countries respectively. The 4-year filling option, as the shorter period of filling, would be beneficial to Ethiopia to yield its huge investment and support its economy. This option will also be beneficial to downstream and other neighbouring countries to getting a relatively cheaper electricity from Ethiopia as soon as possible. Sudan's hydropower ${ }^{322}$ and potentially agriculture, will also benefit from GERD's full-scale flow. This option was used when filling the Aswan High Dam in Egypt without causing a major crisis on Egyptian agriculture, hydropower and other economic activities there. ${ }^{323}$ However, the GERD is built on the Blue Nile which makes around $60 \%$ of Nile waters, Egyptian agriculture, fisheries and hydropower might (or might note) sustain significant harm, even if temporarily, if Ethiopia fills the GERD in four or less years' period. ${ }^{324}$ For this reason, this option may not provide a fair result and is less likely to attract consensus from the three countries.

The $10+$ years' option is equivalent to a filling of $10 \%$ monthly streamflow ${ }^{325}$ of the Blue Nile. This filling option will certainly benefit Egypt and perhaps Sudan as the GERD filling won't be felt much downstream. In turn, Ethiopia will not get its investment returns including satisfying its acute electricity demands, leave alone to sale to neighbouring countries. This option is not thus only detrimental to Ethiopia but also to the region as it defeats the regional integration aims and objectives of the GERD as adopted in the DoPs. This option also fundamentally defeats the essence of distributive justice as it effectively blocks the enjoyment of legal rights by Ethiopia and its people.

It was proposed that the 6 and 8-year filling options, with emphasis on the 6 years' period, which is roughly translated to mean an average $25 \%$ monthly streamflow of the Blue Nile

\footnotetext{
${ }^{322}$ Supra Wheeler et al note 295, p. 630.

${ }^{323}$ It is quite obvious that Egypt could not possibly fill the huge Aswan High Dam reservoir while negatively affecting its irrigated agriculture.

${ }^{324}$ Zhang et al note 20, p. 608.

${ }^{325}$ Ibid.
} 
can serve as a compromised solution. ${ }^{326}$ This will enable GERD to generate electricity in full capacity to Ethiopia in the medium term, a better flow and flood control to Sudan and a potentially cheaper electricity and a better water flow to Egypt, without causing a significant interruption to the supply needs of downstream communities.

Agreeing on pre-defined number of years for filling may not be the sole option available on the table, or it may be better implemented in conjunction with other approaches. For example, Wheeler et al's ${ }^{327}$ GERD filling scenarios and options avoid pre-defined yearsbased strategy for filling; aiming at eliminating 'all risks of the HAD reaching the minimum power elevation', which is necessary for both hydropower-generation from the HAD and satisfying all other downstream demands, they proposed $35 \mathrm{BCM}$ or more water release per-annum from GERD during the filling period. Such a 'middle ground', they argue, will bring 'increased benefits (for Ethiopia and the region) and reduced downstream risks (for Egypt and Sudan). ${ }^{328}$ This appears to contradict the 'minimum requirement' threshold proposed by the MIT report. In addition to the fixed options, however, Wheeler et al advocates for agreeing on a 'safeguard policy' to release more water when unplanned shortages or drought occur downstream in addition to the $35 \mathrm{BCM}$ annual release. ${ }^{329}$

Given that the total GERD's reservoir capacity is $74 \mathrm{BCM}$, and if the $35 \mathrm{BCM}$ annual release is agreed, GERD would less likely be in full capacity as conceded by the same scholars. ${ }^{330}$ While finding a middle ground to addressing the concerns of downstream Egypt and Sudan is essential, and Ethiopia should aim to do what it takes to minimise any harm on Egypt and Sudan during GERD filling, this ought to be re-balanced by the legitimate interests of Ethiopia including its huge unilateral investment and the temporary

\footnotetext{
${ }^{326}$ Ibid, pp.600-601.

${ }^{327}$ Supra Wheeler et al note 295, pp. 611-634.

${ }^{328}$ Ibid, pp.630-631. Clarification added.

${ }^{329}$ Ibid.

${ }^{330}$ Ibid.
} 
nature of dam filling. What this means is that it may not necessarily be fair to claim a nearly status quo position on water flow during dam filling.

The legal basis for filling, similar to that of dam operation, must be the ones adopted in the DoPs and also available in customary international law-equitable use, no significant harm, cooperation and the likes, and absolutely not existing water quota-based on colonialera treaties. Be that as it may, in addition to, at least, making sure that minimum water supply to Egypt and Sudan is maintained during GERD filling, vital human needs (such as water supply for drinking and sanitation and arguably for subsistence farming $)^{331}$ must not be affected at anytime during dam filling. Affecting such vital needs through human conduct would not server distributive justice to Sudan and Egypt and their communities. This approach should also be adhered to even after the end of dam filling. In brief, the issue of dam filling and dam operation are crucial to understanding the distributive justice results of the GERD. Both areas require an informed decision making and (flexible) agreement. While scholars and consultancy firms may provide some options and scenarios, a fair deal can only be obtained through good faith negotiations. As there is no rigid qualitative or empirical formula that can be used to implement accurate fairness for the three countries some compromises must be made to balance the costs and benefits of the filling and operation of the GERD. Such compromises shall take into account situations of drought, water availability in Sudanese and Egyptian reservoirs and wetter and drier seasons so as to prevent significant harm downstream. This ought to be done on a firm belief, as required by the DoPs, that filling, operation and utilisation of GERD in a coordinated fashion would bring a fair result to the three countries, their communities, the

${ }^{331}$ Supra UNWCC note 65, Art 10 which is about the:

Relationship between different kinds of uses (states that)

1.In the absence of agreement or custom to the contrary, no use of an international watercourse enjoys inherent priority over other uses.

2.In the event of a conflict between uses of an international watercourse, it shall be resolved with reference to articles 5 to 7 , with special regard being given to the requirements of vital human needs. (Italics and 'states that' added). 
region and the natural environment. ${ }^{332}$ Apparently, this is not going to be an easy task to accomplish.

\section{Hopes and Challenges of Ensuring Distributive Justice}

The tripartite recognition of the core principles of customary watercourses law, supported by further details of operation and management of the dam must be commended as a step in the right direction. Yet translating the detailed factors for equitable use and preventing significant harm into something concrete would still be a delicate matter be it in relation to dam filling, dam operation or in general terms. Two examples are offered to illustrate this challenge generally. The first is how to assess the water needs of downstream Egypt (and Sudan) and upstream Ethiopia. With respect to the water needs of both sides, following the signing of the DoPs, President Al-Sisi told the Ethiopian Parliament in March 2015 that:

I invite you today to jointly lay the foundations of a better future for our children and grandchildren, a future where all the classrooms in Ethiopia are lit and all the children of Egypt can drink from the River Nile as their fathers and grandfathers did. ${ }^{333}$

This is consistent with previous policy of Egypt which sees the Nile as a matter of life and death for Egypt, while a question of development or energy provision for Ethiopia. ${ }^{334}$ The Nile is undoubtedly vital for the livelihood and the existence of millions of Egyptians, although it is well documented that Egypt also has renewable and non-renewable

\footnotetext{
332 This approach is adopted for example in the Southern African Development Communities (SADAC) region see Revised Protocol on Shared Watercourses (2000), Art 2 (c) http://www.sadc.int/files/3413/6698/6218/Revised_Protocol_on_Shared_Watercourses_-_2000_English.pdf.

333 'Egypt stresses Nile water rights in Ethiopia dam project' Daily Mail (25 March 2015) http://www.dailymail.co.uk/wires/afp/article-3011635/Egypt-stresses-Nile-water-rights-Ethiopiadam-project.html.

${ }^{334}$ Supra Egypt's Perspective note 5.
} 
groundwater (aquifer) resources which can supplement current Nile water uses by the Country. ${ }^{335}$

The president's characterisation of the water needs of both countries, if only applicable to the GERD seems reasonable. However, that does not seem to be the case if the statement is read in conjunction with Egyptian Constitution and policy. If such determination of the water needs of the parties concerned is correct, either in its limited or broader senses, it would be in the interest of distributive justice to give priority to Egypt (and Sudan) over Ethiopia and the rest of upstream countries' water needs. Any use of Nile waters contrary to 'vital human needs' of downstream populations would contravene the distributive justice component of fairness. ${ }^{336}$ The GERD National Panel of Expert, however, asserts that

...of all African Countries, surely of all Nile Basin countries, it is only Egypt that has over $98 \%$ of its population with access to potable water, while an Ethiopian girl of sixteen has to go on average 6 kilometres each day back and forth to fetch a gallon of water from a river or a dug hole...., 337

Worthy of mention is the fact that fetching water is only possible in Ethiopia if it is available on the ground, which entirely relies on adequate rainfall.

The second example concerns the challenge of applying socio-economic needs as a factor for determining equitable water use of Egypt and Ethiopia. In articulating why Ethiopia 'won' the diplomatic and legal battle regarding the GERD, Salman argues that:

335 Abdel-Shafy, H. I., \& Aly, R. O., 'Water Issue in Egypt: Resources, Pollution and Protection Endeavours' Central European Journal of Occupational and Environmental Medicine Vol. 8(1) pp. 3-21 (2002) http://www.omfi.hu/cejoem/Volume8/Vol8No1/CE02_1-01.html, pp. 3-21; Eckstein, G. G. E., Hydrologic Reality: International Water Law and Transboundary GroundWater Resources, paper and lecture for the conference on 'Water: Dispute Prevention and Development' (American University Centre for the Global South, Washington, D.C., 12-13 October 1998).

${ }^{336}$ Supra UNWCC note 65, Art. 10.

337 'A Proxy Campaign against Ethiopia? A Response by GERD National Panel of Experts (NPoE)' Ethiopian International Professional Support for Abay/Nile (EIPSA) Vol. 1(3) pp. 1-9 (2014) http://www.eipsa1.com/cms/articles/GERDFINALNPOERebuttalIRN.pdf, p.5 . 
Ethiopia has relied in its strategy on the fairness of its cause as it is the source of $86 \%$ of the Nile water while it uses only $1 \%$ of that Nile water. Yet it continued undergoing successive famines, especially those of 1983-85 which claimed about a million lives, in addition to the crushing poverty the Ethiopian people are suffering from. ${ }^{338}$

As we write and debate the fairness of the GERD, Ethiopia is trying to heal its wounds from the severe drought which affected millions of its citizens. ${ }^{339}$ This is likely to reoccur, unless the country's total dependency on rainfall for agriculture ceases to exist.

Undeniably, Egypt is richer than Ethiopia in food security, drinking water availability and economic development terms. Recent data shows that Egypt's per Capita income is $\$ 3,950.7$ while Ethiopia's $\$ 567.8 .^{340}$ Extreme poverty in upstream countries including Ethiopia is ubiquitous; lack of class-room and home light in most parts of rural Ethiopia is just one aspect of the problem. Millions of Ethiopians need food, basic closing, shelter and health services, despite the economic progress made in recent years. What this means is that Ethiopia's need to use the Blue Nile (or other tributaries) is neither a question of luxury nor limited to generating electricity.

Yet such apparent inequality between Egypt and Ethiopia may be accepted or accommodated for the reason that distributive justice 'recognises' or appreciates disparity in countries' wealth and development as an inevitable fact. ${ }^{341}$ International (watercourses) law firmly favours 'the achievement of more rational and equitable international economic relations. ${ }^{342}$ It is doubtful that the DoPs impliedly endorses inequality as a factor for

\footnotetext{
${ }^{338}$ Salman, S., 'How and Why has the Ethiopian Strategy on the Renaissance Dam Succeeded?' Sudan Vision, (25 May 2015), http://news.sudanvisiondaily.com/details.html?rsnpid=248051.

${ }^{339}$ Myrie, C., 'El Nino threatens 'millions in east and southern Africa' BBC News (10 November 2015) http://www.bbc.co.uk/news/uk-34779447.

${ }^{340}$ GDP per capita (2010-2014 Data), World Bank, http://data.worldbank.org/indicator/NY.GDP.PCAP.CD .

341 (supra sec [features and challenges of fairness].

${ }^{342}$ Supra Charter of Economic Rights note 56, preamble, para. [a]. This resolution asserts, under Article 2(1), on the one hand, that 'Every State has and shall freely exercise full permanent sovereignty, including possession, use and disposal, over all its wealth, natural resources and
} 
sharing Nile resources. Whatever the position of the law may be on inequality, the principle of fairness requires working towards narrowing gaps in wealth. ${ }^{343}$

Surely, the post-1990 undertakings are basically different from the old Nile treaties in that they aimed at addressing the fairness dilemma; given the uncertainties surrounding them, however, it may be question whether they are part of the dilemma at issue. As the next final part of the monograph demonstrate, however, they can lead to a way out from the fairness dilemma in the sharing of water resources in the Nile basin.

\section{Concluding Remarks: Lessons to be Learnt?}

After a careful analysis of the salient features of justice, equity and fairness, the monograph enlightens that the latter provides a solid legal basis to the sharing of transboundary resources. More specifically, the UNWCC and basin-specific (existing or emerging) regimes such as the CFA, represent a system of fair deal of sharing transboundary water resources. Such a system contests the (unjustified) rejection of distributive justice and its narrow construction in the equity discourse. As the eastern Nile basin countries are not parties to the UNWCC and the CFA (excepting Ethiopia), Frank's theory of fairness has been tested with particular reference to the fairness of the GERD from colonial-era Nile treaties, post-1990 commitments and customary international law perspectives. The following five concluding remarks are drawn from the in-depth analysis made of the various instruments and applicable customary rules with the aims of addressing the questions asked at the outset.

Firstly, despite the use of Nile colonial-era treaties to challenge the procedural and substantive fairness of the GERD, they are not compatible with the dictates of fairness.

economic activities.' Under Article 3, on the other hand, it states that: 'In the exploitation of natural resources shared by two or more countries, each State must co-operate on the basis of a system of information and prior consultations in order to achieve optimum use of such resources without causing damage to the legitimate interest of others.'

${ }^{343}$ Supra Franck note 28. 
The real question or dilemma is thus whether they still exist or are laid to rest with the adoption of the DoPs. One observation may be that they are still alive and violated by the GERD project. ${ }^{344}$ The opposite and perhaps stronger observation is that, as they are totally rejected by most Nile co-riparians, as both procedurally and substantively flawed instruments, they cannot provide a fair system for sharing Nile resources. Worthy of note is that they are not suitable for compromises and negotiations. It follows from this that the fairness of the GERD ${ }^{345}$ cannot be questioned on the basis of these treaties. In fact, the real question is now whether the signing of the DoPs and the endorsement of the GERD by all Nile riparians, notably by Sudan and Egypt, have closed the existence of colonial-era Nile treaties for good. This conclusion includes the 1959 Nile Treaty which is at odds with the DoPs, the 1993 instrument, newly emerging Nile basin initiatives and conventional and customary international watercourses law. The lesson that should be learnt here is that unfair laws and practices cannot be considered as valid merely on technical (or procedural) grounds in modern international law, as the next key remarks further illustrate.

Secondly, is the question of whether the 1993 and 2015 commitments, in contrast to the old Nile treaties, support or challenge the fairness of building, filling, operating and sharing the costs and benefits of the GERD. The first aims to promote joint studies for utilising Nile waters, without providing specific and complete procedural and substantive rules, which makes it either less attractive to assess the fairness of GERD or a commitment entirely disregarded by both parties as a result of the dominant practice of unilateralism rather than genuine cooperation in the (eastern) Nile basin. Thus, it became, although not at the level of the old treaties, part of the fairness dilemma, rather than resolving it. However, the 2015 instrument (DoPs), either as a legally binding commitment or

\footnotetext{
344 'Cairo University's Report on Ethiopia's Great Renaissance Dam', Group of Nile Basin (GNB) at Cairo University to Support Egypt (2013), Egyptian Chronicles, http://web.mit.edu/12.000/www/m2017/pdfs/ethiopia/cairo.pdf.

${ }^{345}$ Supra MIT Report note 10, p. 11.
} 
declaratory of conventional and customary rules, has changed the rules of the game in the use of Nile waters for the better. The impacts of this development to the fairness question is twofold. Firstly, unlike colonial-era treaties, and to some extent, the 1993 engagement, the DoPs has secured the full participation of the three main Nile riparians; this endeavour was assisted by an IPoE and by international firms in the quest of the parties to find a winwin, proportionate and fair deal on the basis of modern principles of international watercourses law. Furthermore, the mechanisms introduced to implement the Declaration ranging from establishing joint national technical committees to that of heads of State/Government along the specific commitments to exchange information are significant achievements of cooperation. Clearly, these fulfil the dictates of procedural fairness as all the parties supported by international actors are participating in an equal footing. Secondly, the substance of the declaration, comprising the principles of equitable use, no significant harm, sustainable use, protecting the environment, dam safety and clean energy sharing reflect the hopes and fears of all the parties, and signify a system of distributive justice. For these reasons the DoPs, as an initial but a significant step in the right direction, meets the test of 'perceived fairness, ${ }^{, 346}$ in effect, makes the GERD as a classic example of fairness in action and the DoPs as the best, if not absolute, tool adopted to unlock the fairness dilemma in the (eastern) Nile basin.

Thirdly, this unprecedented development has, however, encountered multifaceted challenges which range from a lack of shared understanding on relevant factors for equitable use, notably water and socio-economic needs of the parties involved, contested claims over the effects and benefits to that of resistance to change from both ends (excluding Sudan). Particularly, dam filling, dam operation and associated studies are leading to major differences. It is worthy of emphasis here that maximising the benefits of

${ }^{346}$ Supra Franck note 28, p. 13. 
the GERD while preventing and reducing potential consequences, as key components of the GERD's fairness, can only be achieved if the parties keep the momentum of cooperation and promote reasonable benefit sharing ${ }^{347}$ which should underpin existing projects of cooperation such as the NBI. This provides both the opportunities and challenges to get rid of the dilemma over extreme claims and counter-claims for good. This requires clearing the current tense political fog which appears to be covering the eyes and minds of both sides from keeping the momentum of good faith negotiations and cooperation.

Fourthly, the two instruments signed in the last two to three decades represent the aspirations of the parties to cooperate at a basin-level. In particular, the DoPs' ambition to promote 'transboundary cooperation and regional integration' 348 along its endorsement of all principles of the CFA 2010 is a positive step towards regional cooperation. Yet, there has been no signal sent yet to spread this fair system to basin-level collaboration. ${ }^{349}$ Tanzania's immediate ratification of the CFA after the GERD's declaration is signed ought to be noted to which other Basin countries may follow suit. This raises the question, if Egypt and Sudan signed the DoPs, why not the CFA 2010?

One theory may be that they do not want to put legal constraints on their current use of Nile waters, assuming that the DoPs is not a hard law. The other more persuasive theory is that what has already been agreed with respect to the GERD represents contemporary legal principles and practices that are beneficial to all Nile co-riparians for securing their water share, and for being notified and consulted on future planned measures which will end existing unilateral practices and contentious projects. Such a basin level approach would also give a fairer result on the river and the environment with good returns to all. This is

\footnotetext{
347 Sadoff, C. W., \& Grey, D., 'Beyond the River: The Benefits of Cooperation on International Rivers' Water Policy Vol. 4 pp. 389-403 (2002).

${ }^{348}$ Supra DoPs note 12, Art. II.

${ }^{349}$ Supra Kimenyi \& Mbaku note 121.
} 
not withstanding the need for a global cooperation and the likelihood that (some) Nile basin states may (or may not) seriously consider acceding to the UNWCC sooner or later. The message here is, therefore, while the bottom-up approach to fostering fairness is necessary such endeavours need to be reinforced by global, regional or basin-wide legal framework for a greater cooperation, coordination and sustainable use of resources.

Finally, this monograph has demonstrated that without looking into the way in which laws come into being and the nature of their specific content on a case-by-case basis, it is difficult, if not impossible, to judge them as just or unjust under contemporary international law. For example, Article 3 (1) of the UNWCC appears to respect the integrity and validity of existing treaties among states when becoming parties to the Convention, although paragraph 2 of the same article offers the option for harmonisation. What if an existing agreement of two or more states is at odds with the fundamentals of the Convention itself and general international law? Would they be able to join? Some wish to interpret this ${ }^{350}$ as an absolute safeguard clause to prior or later water agreements, unless concerned parties wilfully opt for harmonising them with the terms and spirit of the UNWCC. The International Law Commission (ILC) rightly clarified the question, within the spirit of paragraph 4 of the same article, however, that:

if a watercourse agreement is concerned with only part of the watercourse or only a particular project, programme or use relating thereto, it must be subject to the proviso that the use, by one or more other watercourse States not parties to the agreement, of the waters of the watercourse is not, to a significant extent, adversely affected by the agreement. Otherwise, a few States of a multi-State international watercourse could appropriate a disproportionate amount of its benefits for themselves or unduly prejudice the use of its waters by watercourse States not parties to the agreement in question. Such

${ }^{350}$ See e.g. supra Aal note 156, pp28-29. 
results would run counter to fundamental principles which will be shown to govern the non-navigational uses of international watercourses, such as the right of all watercourse States to use an international watercourse in an equitable and reasonable manner and the obligation not to use a watercourse in such a way as to injure other watercourse States. ${ }^{351}$ This has a wider connotation in international law. If a treaty or custom is failing to meet the test of fairness in both its aspects, taking into account, historical, societal and legal developments in a given field, it has to be disbanded or revised.

As fairness can be relative, it is imperative to distinguish between making laws fairer and better in general terms from dealing with existing laws that defeat inter alia equality, sovereignty and equity which form among the key constituents of fairness. This may be criticised as a source of uncertainty in international law by those who overly rely on formalism and treaty (un)making and retaining techniques.

However, those who see international law as a dynamic subject will argue that a formal process may not necessarily be procedurally fair; and even if it is so, the content of which may or may not be fair. If law is not flexible to adapt to changes and to correct historic or existing unfairness in their all forms, it will cause more havoc than stability in the international community in general and in affected regions in particular. This key lesson from the developments in the Nile is something international law cannot afford to ignore as doing so may further destabilise the system and erode confidence of community of states and their populations on the system, as justly envisaged and theorised by the great public international law scholar, Thomas Franck. ${ }^{352}$

\footnotetext{
${ }^{351}$ ILC Draft articles on the law of the non-navigational uses of international watercourses and commentaries thereto, 1994. http://legal.un.org/ilc/texts/instruments/english/commentaries/8_3_1994.pdf.

${ }^{352}$ Supra Franck note 28, p. 7.
} 


\section{Acknowledgements:}

The author is grateful to Alistair Rieu-Clarke, Salman Salman, Abbe Brown, Emily Hirst, Melaku Desta and the anonymous reviewers for their valuable comments on earlier or later drafts. Thanks also to Saloni Sudan for her kind research assistance. Any error or omission is of the author's.

This research builds upon previously published work with Water International: Yihdego,

Z. \& Rieu-Clarke, A. 'An Exploration of Fairness in International Law through the Blue Nile and GERD', Water International (2016) Vol 41, Number 4, pp.528-559. DOI:10.1080/02508060.2016.1196321. 


\section{List of Bibliography}

'A dam nuisance: Egypt and Ethiopia quarrel over water' The Economist (20 April 2011) http://www.economist.com/node/18587195

'A Proxy Campaign against Ethiopia? A Response by GERD National Panel of Experts (NPoE)' Ethiopian International Professional Support for Abay/Nile (EIPSA) Vol. 1(3) pp. 1-9 (2014) http://www.eipsa1.com/cms/articles/GERDFINALNPOERebuttalIRN.pdf

'Al-Sisi criticised for waiving Egypt's right over Nile water' Middle Eastern Monitor (23 March 2015) https://www.middleeastmonitor.com/news/africa/17657

'Alstom to supply hydroelectric equipment for the Grand Renaissance dam in Ethiopia' 07/01/2013 http://www.alstom.com/press-centre/2013/1/alstom-to-supply-hydroelectricequipment-for-the-grand-renaissance-dam-in-ethiopia/

'Egypt Forced to Negotiate on Nile Dam' Stratfor (20 March 2015) https://www.stratfor.com/sample/analysis/egypt-forced-negotiate-nile-dam

'Egypt stresses Nile water rights in Ethiopia dam project' Daily Mail (25 March 2015) http://www.dailymail.co.uk/wires/afp/article-3011635/Egypt-stresses-Nile-water-rightsEthiopia-dam-project.html

'Egypt, Ethiopia, Sudan sign final contracts on Nile dam studies' Ahramonline (10 Sep, 2016).

'Egypt's Sisi denies supporting opposition in Ethiopia' (Reuters 13 October, 2016).

'Ethiopia inaugurates Africa's first ever biggest power dam' (Sudan Tribune, 14 November, 2009)

'Ethiopia won't stop construction of the Renaissance Dam: minister' (Sudan Tribune, 13 February, 2016)

'GERD to start generate $750 \mathrm{MW}$ soon' EBC (15 October, 2015) 
'International Panel of Experts (IPoE) on the Grand Ethiopian Renaissance dam Project (PERDP) http://www.internationalrivers.org/files/attachedfiles/international_panel_of_experts_for_ethiopian_renaissance_dam-_final_report_1.pdf

'Sudan to build power transmission line from Ethiopia's GERD: minister' (Sudan Tribune, 28 October, 2016) http://www.sudantribune.com/spip.php?article60680

'The Grand Ethiopian Renaissance Dam: An Opportunity for Collaboration and Shared Benefits in the Eastern Nile Basin', MIT Abdul Latif Jameel World Water and Food Security Lab (2014)

Aal, M. S., 'Equitable and Reasonable Utilization of International Rivers in the UN Convention with a Particular Reference to the River Nile' African Perspectives Vol. 11(39) pp. 22-28 (2013)

Abdelatti, A., 'Egypt's Sisi denies supporting opposition in Ethiopia' (Reuters, 13 October, 2016) http://uk.reuters.com/article/uk-ethiopia-unrest-egypt-idUKKCN12D2L5

Abdel-Shafy, H. I., \& Aly, R. O., 'Water Issue in Egypt: Resources, Pollution and Protection Endeavours' Central European Journal of Occupational and Environmental Medicine Vol. 8(1) pp. 3-21 (2002) http://www.omfi.hu/cejoem/Volume8/Vol8No1/CE02_1-01.html Abdo, M., 'The Nile Question: The Accords on the Water of the Nile and Their Implications on Cooperative Schemes in the Basin' Perceptions Summer (2004) http://sam.gov.tr/wpcontent/uploads/2012/01/4.-Mohammed-Abdo.pdf

Abulwafa, A., 'Commitment of International Conventions on the River Nile' African Perspectives Vol. 11(39) pp. 7-13 (2013) http://www.sis.gov.eg/newvr/afaken39/3.pdf

Act to amend the National Dam Safety Program Act to reauthorize the national dam safety program, and for other purposes, 22 December 2006, Public Law 109-460 [USA] https://www.congress.gov/109/plaws/publ460/PLAW-109publ460.pdf Aegean Sea Continental Shelf Case (Greece v Turkey) ICJ Repts 1978 
Afifi, H., 'Egyptian experts divided over Renaissance Dam declaration of principles' Ahramonline (24 March 2015)

Agreement on Declaration of Principles between the Arab Republic of Egypt, the Federal Democratic Republic of Ethiopia and the Republic of the Sudan on the Grand Ethiopian Renaissance Dam Project (GERDP), 23 March 2015

Agreement on the Nile River Basin Cooperative Framework (CFA), May 2010, The States of the Nile River Basin

Akehurst, M., 'Equity and General Principles of Law' The International and Comparative Law Quarterly Vol. 25(4) pp. 801-825 (1976)

Ali N., 'Ethiopia Accuses Egypt of Destabilizing the Country by Supporting Rebels' (Middle East Observer, 11 October, 2016)

Allan, J. A., \& Mirumachi, N., 'Why Negotiate? Asymmetric Endowments, Asymmetric Power and the Invisible Nexus of Water, Trade and Power That Bring Apparent Water Security’, in, Earle, A., Jägerskog, A., \& Öjendal, J., Transboundary Water Management: Principles and Practice pp. 13-26 (Earthscan: London, 2010)

Aman, A., 'Egypt warily signs preliminary Nile agreement' Almonitor (31 March 2015) http://www.al-monitor.com/pulse/originals/2015/03/egypt-eastern-nile-water-agreementethiopia-sudan.html\#

Berhane, D., 'Anti-dam group doctor's report, joins Egypt to stop Ethiopia’s dam' Horn Affairs English (11 April 2014) http://hornaffairs.com/en/2014/04/11/ethiopia-dismissesinternational-rivers-as-egypts-proxy-full-text-included/

Birnie, P., Boyle, A., \& Redgwell, C., International Law and the Environment (3rd ed., Cambridge University Press: Cambridge, 2009)

Boh, E., 'Ethiopia accuses Egypt of 'fuelling' violence' (Africanews, 10 October, 2016) http://www.africanews.com/2016/10/10/ethiopia-accuses-egypt-of-fueling-violence/ 
Boyle, A., \& Chinkin, C., The Making of International Law (Oxford University Press: Oxford, 2009)

Brownlie, I., Legal Status of Natural Resources in International Law (Some Aspects) (Volume 162) (Brill Nijhoff: Leiden, 1979)

Brunnee, J., Toope, S. J., 'The Changing Nile Basin Regime: Does Law Matter?' Harvard International Law Journal Vol. 43(1) pp. 105-159 (2002)

Cairo Declaration on Border Disputes among African States legitimising national borders inherited from colonial times (Cairo Declaration), OAU, 1964

Cairo University's Report on Ethiopia's Great Renaissance Dam', Group of Nile Basin (GNB) at Cairo University to Support Egypt (2013), Egyptian Chronicles,

Cascão, A. E., 'Changing Power Relations in the Nile River Basin: Unilateralism vs. cooperation?' Water Alternatives 2(2) pp. 245- 268 (2009)

Cascão, A., \& Alan Nicol, A., ' GERD: new norms of cooperation in the Nile Basin?, Water International, (2016) Vol41, Issue4, pp. 550-573

Case Concerning Maritime Delimitation and Territorial Questions Between Qatar And Bahrain (Qatar v Bahrain) ICJ Repts 1994

Case Concerning Military and Paramilitary Activities in and Against Nicaragua (Nicaragua v United States of America) Merits, Judgment ICJ Repts 1986

Case Concerning Pulp Mills on the River Uruguay (Argentina v Uruguay) ICJ Judgment of 20 April 2010

Case Concerning Pulp Mills on the River Uruguay (Argentina v Uruguay) Judgment of 20 April 2010 Separate Opinion of Judge Trindade ICJ 2010

Case Concerning the Barcelona Traction, Light and Power Company, Limited (Belgium v Spain) ICJ Second Phase Judgment of 5 February 1970 
Case Concerning the Continental Shelf (Tunisia/Libyan Arab Jamahiriya) Judgment of 24 February ICJ Repts 1982

Case Concerning the Frontier Dispute (Burkina Faso/Republic of Mali) Judgment ICJ 1986

Case Concerning the Gabčikovo-Nagymaros Project (Hungary v Slovakia) (ICJ 25 September 1997) 37 ILM 162 (1998)

Case Concerning the Land and Maritime Boundary Between Cameroon and Nigeria (Cameroon v Nigeria: Equatorial Guinea intervening) ICJ Repts. 2002

Case Relating to the Territorial Jurisdiction of International Commission of the River Oder (United Kingdom v Poland) PCIJ Series A No 23 Annex 3 (Order made on 20 August 1929)

Charter of Economic Rights and Duties of States, 12 December 1974, Resolution 3281 (XXIX), United Nations General Assembly

Charter of the United Nations, 24 October 1945

Constitution of the Arab Republic of Egypt, 18 January 2014,

Constitutive Act of the African Union, 11 July 2000

Convention on the Cooperation for the Protection and Sustainable Use of the Danube River (Danube River Protection Convention) June 29, 1994 (entered into force Oct. 22, 1998) https://www.icpdr.org/main/icpdr/danube-river-protection-convention

Convention on the Law of the Non-navigational Uses of International Watercourses (UNWCC), 21 May 1997, United Nations

Craven, M. C. R., 'The Problem of State Succession and the Identity of States under International Law’ European Journal of International Law Vol. 9 pp. 142-162 (1998)

Crawford, J., Brownlie's Principles of Public International Law (8 ed., Oxford University Press: Oxford, 2012) 
Declaration on Principles of International Law concerning Friendly Relations and Cooperation among States in accordance with the Charter of the United Nations. 24 October 1970, Resolution 2625 (XXV), United Nations General Assembly

Declaration on the Granting of Independence to Colonial Countries and Peoples, 14 December 1960, Resolution 1514 (XV), United Nations General Assembly

Degefu, G. T., The Nile: Historical, Legal and Developmental Perspectives, (Trafford Publishing: New York, 2003)

Dellapenna, J. W., 'The customary international law of transboundary fresh waters', International Journal of Global Environmental Issues (2001) Volume 1, Issue 3-4, pp 264305

Dispute Regarding Navigational and Related Rights [San Juan River Cases] (Costa Rica V. Nicaragua) ICJ Judgment of 13 July 2009

DOI:10.1080/02508060.2010.533642

DoPs by Ahramonline http://english.ahram.org.eg/News/125941.aspx

Eckstein, G. G. E., Hydrologic Reality: International Water Law and Transboundary Ground-Water Resources, paper and lecture for the conference on 'Water: Dispute Prevention and Development' (American University Centre for the Global South, Washington, D.C., 12-13 October 1998)

Egypt announces postponement of GERD impact studies contracts signing' (Ahramonline, 4 September, 2016)

Egypt, Ethiopia, Sudan sign final contracts on Nile dam studies' (Ahramonline, 20 September, 2016)

Egypt's Perspective towards the Ethiopian Grand Renaissance Dam Project (GERDP), allAfrica, http://allafrica.com/stories/201512072751.html 
Eleiba, A., 'Sudanese president backs Ethiopian dam ahead of Nile talks' Ahramonline (5 December

http://english.ahram.org.eg/NewsContent/2/8/88321/World/Region/Sudanese-presidentbacks-Ethiopian-dam-ahead-of-Ni.aspx

EU Water Framework Directive, 2000/60/EC, 23 October 2000.

Farid, S., 'Will Egypt still get its fair share of Nile water?' Al Arabiya News (31 March 2015) http://english.alarabiya.net/en/perspective/analysis/2015/03/31/Will-Egypt-still-get-itsfair-share-of-Nile-water-.html

Framework for General Co-operation between the Arab Republic of Egypt and Ethiopia, 1 July 1993 http://gis.nacse.org/tfdd/tfdddocs/521ENG.pdf

Framework for general cooperation between the Arab Republic of Egypt and Ethiopia 1993, UNTS, Vol. 2693, No. 47816

Franck, T., Fairness in International Law and Institutions (Clarendon Press: Oxford 1995)

Frontier Dispute (Burkina Faso/Niger) Judgment ICJ Repts 2013

Frontier Dispute (Burkina Faso/Niger) Separate Opinion of Judge Yusuf ICJ 2013 http://www.icj-cij.org/docket/files/149/17312.pdf

Garreston, A. H. 'The Nile Basin', in, Garreston, A. H., Hayton, R. D., \& Olmstead C. J., The Law of International Drainage Basins pp. 256-297 (Oceana: New York, 1967)

Garretson, A. H., 'The Nile River System' Proceedings of the American Society of International Law Vol. 54 pp.136-163 (1960)

GDP per capita (2010-2014 Data), World Bank,

Goshu.,S., 'BRLi, Artelia Get Clearance to Conduct GERD Impact Studies' Ethiopian Reporter (24 Sep, 2016).

Grand Ethiopian Renaissance Dam, EEPCo (Ethiopian Electric Power Corporation), http://www.eepco.gov.et/abouttheproject.php?pid=1\&pcatid=2 
Gray, C., 'The Use of Force and the International Legal Order', in, Evans, M. D., International Law 3rd ed. pp. 615-647 (Oxford University Press: Oxford, 2010)

Grotius, H., The Law of War and Peace, Book III, Chapter 2 (1625)

Hammam, H., A Legal Analysis of the Declaration of Principles on the Grand Ethiopian Renaissance Dam, Public International Law Blog,

Hashim, A., 'The Egyptian Military, Part Two: From Mubarak Onward' Middle East Policy Council, Winter 2011, Volume XVIII, Number 4

Hollis, D. B., The Oxford Guide to Treaties Edited by Bibliographic Information (Oxford University Press: Oxford, 2012)

Hossain, K., 'The Environmental Law-Making Process', in, Alam, S., et al., Routledge Handbook of International Environmental Law pp. 61-76 (Routledge: Abingdon, 2013) http://data.worldbank.org/indicator/NY.GDP.PCAP.CD http://english.ahram.org.eg/NewsContent/1/64/126005/Egypt/Politics-/Egyptian-expertsdivided-over-Renaissance-Dam-decl.aspx http://hornaffairs.com/en/2015/03/25/egypt-ethiopia-sudan-agreement-on-declaration-ofprinciples-full-text/ http://jwafs.mit.edu/sites/default/files/documents/GERD_2014_Full_Report.pdf http://legal.un.org/ilc/publications/yearbooks/english/ilc_1962_v2.pdf http://lonang.com/library/reference/grotius-law-war-and-peace/gro-302/ http://news.sudanvisiondaily.com/details.html?rsnpid=248051 http://web.mit.edu/12.000/www/m2017/pdfs/ethiopia/cairo.pdf http://www.academia.edu/2243972/Supporting the_Nile_Basin_Initiative_A_Political_Analy $\underline{\text { sis_Beyond_the_River }}$ http://www.au.int/en/sites/default/files/ConstitutiveAct_EN.pdf http://www.ebc.et/web/ennews/-/gerd-to-start-generate-750-mw-soon 
http://www.hidasse.gov.et/

http://www.icj-cij.org/docket/files/92/7385.pdf

http://www.internationalrivers.org/resources/the-grand-ethiopian-renaissance-dam-fact$\underline{\text { sheet- } 8213}$

http://www.nilebasin.org/images/docs/CFA\%20-\%20English\%20\%20FrenchVersion.pdf http://www.sis.gov.eg/Newvr/Dustor-en001.pdf

https://law4371.wordpress.com/2015/05/08/a-legal-analysis-of-the-declaration-of-principleson-the-grand-ethiopian-renaissance-dam/

https://treaties.un.org/Pages/showDetails.aspx?objid=08000002802a6733

ILC Draft articles on the law of the non-navigational uses of international watercourses and commentaries thereto, 1994 http://legal.un.org/ilc/texts/instruments/english/commentaries/8_3 1994.pdf

International Law Commission First report on the law of treaties, Yearbook of the International Law Commission, Vol. II, 1962, p. 32

Jennings., R., 'Equity and Equidistance Principles' Annuaire Suisse de Droit International Vol. 27, 31-35 (1986)

Justice, West's Encyclopedia of American Law, edition 2, http://legaldictionary.thefreedictionary.com/justice

Kasimbazi, E.B., 'The impact of colonial agreements on the regulation of the waters of the River Nile’ Water International, 35:6, 718-732 ((2010)

Kelley, M. B., \& Johnson, R. 'Egypt Is Prepared To Bomb All of Ethiopia's Nile Dams' Stratfor Business Insider (13 October 2012) http://www.businessinsider.com/hacked$\underline{\text { stratfor-emails-egypt-could-take-military-action-to-protect-its-stake-in-the-nile-2012- }}$ 10\#ixzz3afm498Zg 
Kimenyi, M., \& Mbaku, J., Governing the Nile River Basin: The Search for a New Legal Regime (Brookings Institution Press: Arlington, 2015)

Klabbers, J., 'The Vienna Convention and Conflicting Treaty Provisions', in, Enzo Cannizzaro, E., \& Arsanjani, M. H., The Law of Treaties Beyond the Vienna Convention pp.192-205 (Oxford University Press: Oxford, 2011)

Kritsiotis, D., 'Imagining the International Community', European Journal of International Law Vol. 13(4) pp. 961-992 (2002)

Lauterpacht, H., The Function of Law in the International Community (Oxford University Press: Oxford, 2011)

Leb, C. \& Tignino, M., 'State Succession to Water Treaties: Uncertainties and Extremes', in, de Chazournes, L. B., Leb, C., \& Tignino, M., International Law and Freshwater: The Multiple Challenges pp. 421-444 (Edward: Cheltenham, 2013)

Legal Consequences of the Construction of a Wall in the Occupied Palestinian Territory Separate Opinion of Judge Owada ICJ Repts 2004

Legal Status of Eastern Greenland PCIJ Series A/B No 53 (5 April 1933)

Lie, J. H. S., 'Supporting the Nile Basin Initiative: A Political Analysis "Beyond the River"” Norwegian Institute of International Affairs (2010)

Lowe, V., 'The Role of Equity in International Law' Australian Yearbook of International Law Vol. 12 pp. 54-81 (1988-89)

Lumumba, P. L. O., 'The Interpretation of the 1929 Treaty and its Legal Relevance and Implications for the Stability of the Region' African Sociological Review 11(1) pp. 10-24 (2007)

Maasho, A., 'INSIGHT-Paying for giant Nile dam itself, Ethiopia thwarts Egypt but takes risks' Reuters (23 April 2014) http://www.reuters.com/article/ethiopia-energyidUSL6N0N91QM20140423\#0yFaPZTMs1UPhfBG.97 
Magsig, B.-O., International Water Law and the Quest for Common Security (Routledge: Cheltenham, 2015)

Maiese, M. \& Burgess, H., Principles of Justice and Fairness, Beyond Intractability, http://www.beyondintractability.org/print/2373

Malanczuk, P., Akehurst's Modern Introduction to International Law (7th ed., Routledge: Cheltenham, 1997)

Maluwa, T., International Law in Post-Colonial Africa (Martinus Nijhoff: Leiden, 1999)

Martens, E., 'Article 102, in, Simma, B., et al, The United Nations Charter: Commentary 3rd ed. Volume 2 pp. 2098-2109 (Oxford University Press: Oxford, 2012)

Matz-Lück, N., 'Framework Conventions as a Regulatory Tool' Goettingen Journal of International Law 1 (2009) 3, 439-458

McCaffrey, S., The Law of International Watercourses (2nd ed., Oxford University Press: Oxford, 1997)

McIntyre, O., 'Utilization of Shared International Freshwater Resources: The Meaning and Role of "Equity” in International Water Law' Water International Vol. 38(2) pp. 112-129. (2013)

McIntyre, O., Environmental Protection of International Watercourses under International Law (Ashgate: Aldershot, 2007)

McKenzie, S. O., 'Egypt's Choice: From the Nile Basin Treaty to the Cooperative Framework Agreement, an International Legal Analysis' Transnational Law \& Contemporary Problems Vol. 21 (2012) http://papers.ssrn.com/sol3/papers.cfm?abstract_id=2445962\#\#

Mekonnen, D. Z., 'The Nile Basin Cooperative Framework Agreement Negotiations and the Adoption of a "Water Security" Paradigm: Flight into Obscurity or a Logical Cul-de-sac?' European Journal of International Law Vol. 21(2) pp. 421-440 (2010), doi: 10.1093/ejil/chq027 
Moyle, J.B., The Institutes of Justinian, 5th ed. (Clarendon Press, Oxford, 1913) http://droitromain.upmf-grenoble.fr/Anglica/just1_Moyle.htm

Myrie, C., 'El Nino threatens 'millions in east and southern Africa' $B B C$ News (10 November 2015) http://www.bbc.co.uk/news/uk-34779447

National Water Act, 6 August 1998, Act No. 36 [South Africa] http://www.acts.co.za/national-water-act-1998/, chapter 12

Negash, M., Hassan, S., Muchie, M., \& Girma, A., 'Perspectives on the Declaration of Principles regarding the Grand Ethiopian Renaissance Dam’ The Thinker Vol. 65 pp. 56$61(2015)$

Nile Treaty 1902 -Blue Nile and Sobat Rivers (tributaries of the Nile) and Lake Tsana (Ethiopia and Sudan): Treaty between Ethiopia and the United Kingdom relative to the frontiers between the Anglo-Egyptian Sudan, Ethiopia and Eritrea, signed at Addis Ababa on 15 May 1902. http://treaties.fco.gov.uk/docs/pdf/1902/TS0016.pdf

Nile Waters: HC Deb 18 May 1956 vol 552 cc2375-412, sec 2395 Retrieved from http://hansard.millbanksystems.com/commons/1956/may/18/nile-waters\#column_2395

Okoth-Owiro, A., 'State Succession and International Treaty Commitments: A Case Study of the Nile Water Treaties' (Occasional Paper, East Africa \# 9, 2004), pp.13-21 http://www.kas.de/wf/doc/kas_6306-544-1-30.pdf;

Permanent sovereignty over natural resources, 14 December 1962, Resolution 1803 (XVII), United Nations General Assembly

Prost., M., \& Camprudi., A. T., 'Against Fairness? International Environmental Law, Disciplinary Bias and Pareto Justice' Leiden Journal of International Law Vol. 25(2) pp. $379-396(2012)$

Protocol for Sustainable Development of Lake Victoria Basin, 29 Nov. 2003, Art 3 (i) Retrieved from http://faolex.fao.org/docs/pdf/mul41042.pdf 
Ratner, R. S., The Thin Justice of International Law: A Moral Reckoning of the Law of Nations (Oxford University Press, Oxford, 2015)

Ratner, S., 'Drawing Better Line: UTI Possidetis and the Borders of New States' American Journal of International Law Vol. 90(4) pp. 590-624 (1996)

Rawls, J., 'Justice as Fairness' The Philosophical Review Vol. 67(2) pp. 164-194 (1958)

Renaissance Dam' GLOBAL DIALOGUE Volume $15 \bullet$ Number 2 • Summer/Autumn 2013-Water:

Richard K. Paisley, K.R., \& Henshaw, W.T., 'Transboundary governance of the Nile River Basin: Past, present and future’ Environmental Development 7 (2013) 59-71

Richard K., Paisley, K.R., \& Henshaw, W.T., 'Transboundary governance of the Nile River Basin: Past, present and future' Environmental Development (July 2013) Volume 7, pages $59-71$

Rieu-Clarke, A., \& Pegram, G. 'Impacts on the International Architecture for Transboundary Waters', in, Loures, F. R., \& Rieu-Clarke, A., The UN Watercourses Convention in Force: Strengthening International Law for Transboundary Water Management pp. 67-76 (Routledge: Abingdon, 2103)

Rieu-Clarke, A., 'Notification and Consultation on Planned Measures Concerning International Watercourses: Learning from the Pulp Mills and Kishenganga Cases' Yearbook of International Environmental Law Vol. 24(1) pp. 102-130 (2014)

Sadoff, C. W., \& Grey, D., 'Beyond the River: the Benefits of Cooperation on International Rivers' Water Policy Vol. 4 pp. 389-403 (2002)

Salama, A., 'The Principle of Fundamental Change in Circumstances and its Impact on the Nile Basin Agreements' African Perspectives Vol. 11(39), pp. 36-40 (2013) 
Salini-Impregilo, GERD's building contractor http://www.saliniimpregilo.com/en/projects/in-progress/dams-hydroelectric-plants-hydraulic-works/grandethiopian-renaissance-dam-project.html

Salman S., 'Downstream Riparians Can Also Harm Upstream Riparians: The Concept of Foreclosure of Future Uses' Water International (2010) Vol. 35(4) pp. 350-364

Salman, S., "Dams, International Rivers, and Riparian States: An Analysis of the Recommendations of the World Commission on Dams." American University International Law Review 16, no. 6 (2001): 1477-1505

Salman, S., 'How and Why has the Ethiopian Strategy on the Renaissance Dam Succeeded?' Sudan Vision, (25 May 2015),

Salman, S., 'The Ethiopian Renaissance Dam: Opportunities \& Challenges' Sudanow (2013) http://sudanow.info.sd/the-ethiopian-renaissance-dam-opportunities-challenges/

Salman, S., 'The Grand Ethiopian Renaissance Dam: The Road to the Declaration of Principles and the Khartoum Document' Water International (2016) Vol 41, Issue 4, pp.512-527

Salman, S., 'The Helsinki Rules, the UN Watercourses Convention and the Berlin Rules: Perspectives on International Water Law' Water Resources Development Vol. 23(4) pp. $625-640(2007)$

Salman, S., 'The Nile Basin Cooperative Framework Agreement: A Peacefully Unfolding African Spring?' Water International Vol. 38(1) pp. 17-29 (2013a)

Salman, S., 'The World Bank Policy for Projects on International Waterways: An Historical and Legal Analysis' (World Bank, 2009)

Scbwelb, E., 'Fundamental Change of Circumstances', Comments on the 1968 Draft Convention on the Law of Treaties (Max-Planck-Institut für ausländisches öffentliches Recht und Völkerrecht, 1999) 
Scobbie, I., 'Tom Franck's Fairness' European Journal of International Law Vol. 13(4) pp. 909-925 (2002)

Separate opinion of Judge Bedjaoui , Gabcikovo case

Shaw, M., 'The Heritage of States: The Principle of uti possidetis juris Today' British Yearbook of International Law Vol. 67(1) pp. 75-154 (1996)

Shelton, D., 'Equity', in, Bodansky, D., Brunnee, J., \& Hey, E, The Oxford Handbook of International Environmental Law pp. 640-661 (Oxford University Press: Oxford, 2007)

Shetewy, M. A., 'Legal Commitments Regulating the Establishment of Water Projects on International Rivers Application Study over the Nile Basin' African Perspectives Vol. 11(39) pp. 29-35 (2013)

Southern African Development Communities (SADAC) Revised Protocol on Shared Watercourses

http://www.sadc.int/files/3413/6698/6218/Revised_Protocol_on_Shared_Watercourses__2000_-_English.pdf

Sutcliffe, J. V., \& Parks, Y. P., The Hydrology of the Nile. (IAHS Press: Wallingford, 1999) http://www.hydrosciences.fr/sierem/produits/biblio/hydrology\%20of\%20the\%20Nile.pdf

Tasioulas, J., 'International Law and the Limits of Fairness' European Journal of International Law Vol 13(4) pp. 993-1023 (2002)

Tawfik, R., The Grand Ethiopian Renaissance Dam: a benefit-sharing project in the Eastern Nile? Water International (2016) Vol 41, Issue 4, pp. 574-592

The Centre of Judicial Studies and Research of the State Council, 'Final Recommendations of the Conference on Nile Basin Agreements in Light of the Provisions of the International Law’ African Perspectives Vol. 11(39) pp. 68-70 (2013)

The Covenant of the League of Nations, 28 April 1919 
The Diversion of Water from Meuse (Netherlands v Belgium) PCIJ Series A/B No 70 (28 June 1937)

The Grand Ethiopian Renaissance Dam - A Symbol of Regional Integration, Ventures Africa, http://www.ventures-africa.com/archives/40137

The Grand Ethiopian Renaissance Dam Fact Sheet, International Rivers,

The Growth and Transformation Plan II (GTP II), Ethiopian National Planning Commission, May, 2016 http://dagethiopia.org/new//docstation/com_content.article/100/gtpii_english_translation_ final_june_21_2016.pdf

The Helsinki Rules on the Uses of the Waters of International Rivers, International Law, August 1966, International Law Association

The Marrakesh Agreement Establishing the World Trade Organization, 1994, 1869 UNTS 299

Tvedt, T., The River Nile in the Post-colonial Age: Conflict and Cooperation in the Nile Basin Countries (I B Tauris \& Co: London, 2009)

Ulfstein, G., 'Reweaving the Fabric of International Law? Patters of Consent in Environmental Framework Agreements', in, Wolfrum, R., Roben, V., Developments of International Law in Treaty Making pp. 145-154 (Springer: Heidelberg, 2005)

United Arab Republic and Sudan Agreement (With Annexes) For The Full Utilization of the Nile Waters, 8 November 1959

Universal Declaration on Human Rights, 10 December 1948, Resolution 217 A(III), United Nations General Assembly

Van Hoof, G. J. H., Rethinking the Sources of International Law, (Kluwer: Berlin, 1983)

Veilleux, J., 'The Human Security Dimensions of Dam Development: The Grand Ethiopian 
Verhoeven, H., Africa's Next Hegemon: Behind Ethiopia's Power Plays, Foreign Affairs, https://www.foreignaffairs.com/articles/ethiopia/2015-04-12/africas-next-hegemon

Vienna Convention on the law of Treaties (with annex), 23 May 1969, United Nations

Vienna Convention on the law of treaties 1969, UNTS No. 18232

Wahish, N., 'Toshka turns millennial green' (Al-Ahram Weekly On-line, 27 Aug. - 2 Sep. 1998, Issue No.392) http://weekly.ahram.org.eg/archive/1998/392/ec1.htm

Wheeler, K., Mohammed Basheer, Mekonnen, Z., Eltoum, S., Mersha, A., Abdo, G., Zagona, E., Hall, J., \& Dadson, S., 'Cooperative filling approaches for the Grand Ethiopian Renaissance Dam', Water International (2016) Vol 41, Issue 4, pp.611-634

Wheeler, K.G., Basheer, M., Mekonnen, Z.T., Eltoum, S.O., Mersha, A., Abdo, G.M., Zagona, E.A., Hall, J.W., \& Dadson, S.J., 'Cooperative filling approaches for the Grand Ethiopian Renaissance Dam’ Water International (2016) Vol 41, Issue 4, pages: 611-634

Wheeler, K.G., Basheer, M., Mekonnen, Z.T., Eltoum, S.O., Mersha, A., Abdo, G.M., Zagona, E.A., Hall, J.W., \& Dadson, S.J., 'Cooperative filling approaches for the Grand Ethiopian Renaissance Dam' Water International (11 May 2016): (DOI:10.1080/02508060.2016.1177698

Whittington, D., Waterbury, J., \& Jeuland, M., 'The Grand Renaissance Dam and Prospects for Cooperation on the Eastern Nile' Water Policy Vol. 16(4) pp. 595-608 (2014), doi: 10.2166/wp.2014.011

Woldetsadik, T. W., International Watercourses Law in the Nile River Basin: Three States at a Crossroads (Routledge: Abingdon, 2013)

Wolfrum, R., 'Commentary on Purposes and Principles (Art 1)', in, Simma, B., Khan, D. E., Nolte, G., \& Paulus, A., The Charter of the United Nations: A Commentary 3rd ed. Volume 1 pp. 113-114 (Oxford University Press: Oxford, 2012) 
Wouters, P., International Water Law: Selected Writings of Professor Charles B. Bourne (Martinus Nijhoff: Leiden, 1997)

Yigzaw, Z.A., Open Letter to Egypt: A Response to The Spokesman of Egypt's Ministry of Foreign Affairs Regarding the GERDP from An Ethiopian Perspective, Sodere, http://sodere.com/profiles/blogs/open-letter-to-egypt-a-response-to-the-spokesman-ofegypt-s.

Yihdego, Z., 'Arms Control and Human Security: What Role for NSAs?', in, Ryngaert, C., \& Noortmann, M., Human Security and International Law: The Challenge of Non-State Actors pp.135-174 (Intersentia: Cambridge, 2014)

Yihdego, Z., Rieu-Clarke, A., \& Cascão, A., How has the Grand Ethiopian Renaissance Dam changed the legal, political, economic and scientific dynamics in the Nile Basin? Water International (2106) Vol. 41 , Issue 4, pp. 503-511

Yihdego, Z., The Blue Nile dam controversy in the eyes of international law, Global Water Forum, http://www.globalwaterforum.org/2013/06/18/the-blue-nile-dam-controversy-inthe-eyes-of-international-law/

Zaher, A., 'Egypt-Ethiopia tension set to rise' The Arab Weekly, 2016/10/23 Issue: 78

Zhang, Y., Erkyihum, S., \& Block, P., 'Filling the GERD: evaluating hydroclimatic variability and impoundment strategies for Blue Nile riparian countries', Water International (2016) vol. 41, Issue 4, pp. 593-610.

Zhang, Y., Erkyihum, S.T., \& Block, P. 'Filling the GERD: evaluating hydroclimatic variability and impoundment strategies for Blue Nile riparian countries', Water International (27 Apri, 2016): DOI:10.1080/02508060.2016.1178467. 